\title{
Ontogenic effects of early feeding of sea bass (Dicentrarchus labrax) larvae with a range of dietary $n-3$ highly unsaturated fatty acid levels on the functioning of polyunsaturated fatty acid desaturation pathways
}

\author{
Marie Vagner $^{1}$, Jean H. Robin ${ }^{1}$, José L. Zambonino-Infante ${ }^{1}$, Douglas R. Tocher ${ }^{2}$ \\ and Jeannine Person-Le Ruyet ${ }^{1}$ \\ ${ }^{1}$ UMR 1067 INRA-Ifremer-Bordeaux 1, Ifremer Centre de Brest, BP 70, 29280 Plouzané, France \\ ${ }^{2}$ Institute of Aquaculture, University of Stirling, Stirling FK9 4LA, UK \\ (Received 31 January 2008 - Revised 28 August 2008 - Accepted 29 August 2008 - First published online 7 October 2008)
}

Four replicated groups of sea bass (Dicentrarchus labrax) larvae were fed diets containing an extra-high level of highly unsaturated fatty acids (HUFA) (XH; $3.7 \%$ EPA + DHA), a high level of HUFA (HH; 1.7\%), a low level of HUFA (LH; 0.7\%) or an extra-low level of HUFA (XLH; $0.5 \%$ ) from day 6 to day 45 (experiment 1; XH1, HH1, LH1, XLH1). After a subsequent 1-month period feeding a commercial diet $\left(2.7 \%\right.$ EPA + DHA), the capacity of the four initial groups to adapt to an $n-3$ HUFA-restricted diet $\left(0 \cdot 3 \%\right.$ EPA + DHA; R-groups: XH2 ${ }_{\mathrm{R}}$, $\mathrm{HH} 2_{\mathrm{R}}, \mathrm{LH} 2_{\mathrm{R}}, \mathrm{XLH} 2_{\mathrm{R}}$ ) was tested for $35 \mathrm{~d}$. Larval dietary treatments had no effect on larval and juvenile survival rates. The wet weight of day 45 larvae was higher in XH1 and HH1 $(P<0.001)$, but the R-juvenile mass gains were similar in all treatments. $\Delta-6$-desaturase $(\Delta 6 \mathrm{D})$ mRNA level was higher in LH1 and XLH1 at day $45(P<0 \cdot 001)$, and higher in $\mathrm{LH} 2_{\mathrm{R}}$ and XLH2 $2_{\mathrm{R}}$, with a significant increase at day $118 . \mathrm{Con}-$ comitantly, PPAR $\alpha$ and PPAR $\beta$ mRNA levels were higher in XLH1 at day 45 , and PPAR $\beta$ and $\gamma$ mRNA levels were higher in XLH2 $2_{\mathrm{R}}$ at day 118 , suggesting possible involvement of PPAR in stimulation of $\triangle 6 \mathrm{D}$ expression, when drastic dietary larval conditioning occurred. The low DHA content in the polar lipids (PL) of LH1 and XLH1 revealed an $n$-3-HUFA deficiency in these groups. Larval conditioning did not affect DHA content in the PL of R-juveniles. The present study showed (i) a persistent $\Delta 6 \mathrm{D}$ mRNA enhancement in juveniles pre-conditioned with an $n$-3 HUFA-deficient larval diet, over the 1-month intermediate period, and (ii) brought new findings suggesting the involvement of PPAR in the $\Delta 6 \mathrm{D}$ mRNA level stimulation. However, such nutritional conditioning had no significant effect on juvenile growth and lipid composition.

Aquaculture: $\Delta$-6 Desaturase: Dicentrarchus labrax: Programming concept

Worldwide supplies of fish oils and meals have reached their sustainable limits, forcing industries to look for alternative lipid sources for use in marine fish diets ${ }^{(1)}$. As terrestrial animal products are prohibited, there is great interest in aquaculture to produce fish better able to utilise vegetable feedstuffs. Vegetable products are rich in eighteen-carbon fatty acids $\left(\mathrm{C}_{18}\right.$ fatty acids) but do not contain $\mathrm{C}_{20-22} n-3$ highly unsaturated fatty acids ( $n-3$ HUFA), such as EPA (20:5n-3) and DHA $(22: 6 n-3)$. These $n-3$ HUFA are required in the diet to provide the essential fatty acids for marine fish, as marine fish have a low capacity to produce $\mathrm{C}_{20-22}$ HUFA from $\mathrm{C}_{18}$ fatty acid precursors, such as $\alpha$-linolenic $(18: 3 n-3)$ and linoleic $(18: 2 n-6)$ acids $^{(2,3)} . \Delta-6$ Desaturase $(\Delta 6 \mathrm{D})$ is the rate-limiting enzyme catalysing the first reaction of $n-3$ HUFA synthesis from $18: 3 n-3$ and $18: 2 n-6^{(4)}$, but, as its activity is very low in marine fish ${ }^{(3,5)}$, it could also limit the use of vegetable products by marine fish.

\begin{abstract}
One solution could be to apply metabolic programming using nutritional conditioning during early larval stages, as already shown in mammals ${ }^{(6)}$, in order to stimulate the fatty acid desaturation pathways of $n-3$ HUFA synthesis in marine fish. We recently showed ${ }^{(7,8)}$ that metabolism in sea bass (Dicentrarchus labrax) juveniles can be modulated by larval nutritional conditioning. The $\Delta 6 \mathrm{D}$ mRNA level was enhanced in larvae fed a low- $n-3$ HUFA diet $(0.8 \%$ DM $\mathrm{EPA}+\mathrm{DHA})$, and this was retained in pre-conditioned juveniles fed an $n-3$ HUFA-restricted diet (0.5\% DM EPA + DHA). Moreover, a slightly, but significantly, higher DHA content in the polar lipids (PL) of pre-conditioned juveniles was measured. However, the larval conditioning did not significantly affect the growth performance of juveniles in terms of weight and survival rates, suggesting that larval nutritional stimulus was not sufficient to induce further long-term effects.
\end{abstract}

Abbreviations: AA, arachidonic acid; C-group, control group; $\Delta 6 \mathrm{D}, \Delta$-6-desaturase; DGI, daily growth index; FAME, fatty acid methyl esters; HH, high-highly unsaturated fatty acid diet; HUFA, highly unsaturated fatty acids; LH, low-highly unsaturated fatty acid diet; NL, neutral lipid; R-group, restricted group; SREBP, sterol regulatory element binding protein; TL, total lipid; XH, extra-high-highly unsaturated fatty acid diet; XLH, extra-low-highly unsaturated fatty acid diet.

* Corresponding author: Dr Marie Vagner, fax +33298 224 653, email marie.vagner@ntlworld.com 
The aim of the present study was to determine the range of dietary $n-3$ HUFA content that would elicit effects on desaturation/elongation pathways for $n-3$ HUFA synthesis and whether the effect could be amplified. Thus, a large range of $n$-3 HUFA dietary content $(0.5-3.7 \%$ EPA + DHA) was used during the larval stage, followed by a severe $n-3$ HUFA-restricted diet (0.3\% EPA + DHA) during the juvenile period.

\section{Materials and methods}

\section{Rearing conditions and experimental design}

Larval conditioning: experiment 1. Sea bass (D. labrax) larvae, at $3 \mathrm{~d}$ post-hatching, were obtained from a commercial hatchery (Gravelines, France), and experiments were conducted at the Ifremer-Brest facility (Brest, France). Larvae were distributed in twenty conical fibreglass tanks (35 litres; initial stocking density was sixty larvae per litre, i.e. 2500 larvae per tank) and temperature was progressively increased from $13 \cdot 5^{\circ} \mathrm{C}$ to $19^{\circ} \mathrm{C}$ within $2 \mathrm{~d}$. All groups were fed microparticulate diets from mouth opening at day 6 to day 45 . Four experimental diets differing only in their $n$-3 HUFA content were tested: extra-high level of HUFA (XH; $3.7 \%$ $\mathrm{EPA}+\mathrm{DHA}$ on a DM basis); high level of HUFA (HH; $1.7 \%$ ); low level of HUFA (LH; $0.7 \%$ ) and extra-low level of HUFA (XLH; $0.5 \%$ ) (Table 1). The different $n$-3 HUFA contents were obtained by the incorporation of soyabean oil in the LH and XLH diets and by an inverse proportion gradient of soya lecithin and marine phospholipid. Four tanks were fed the $\mathrm{HH}$ or $\mathrm{XH}$ diets and six tanks were fed the $\mathrm{LH}$ or XLH diets. The four experimental conditions were $\mathrm{XH} 1$, $\mathrm{HH}$ 1, LH1 and $\mathrm{XLH}$ 1. The rearing conditions were as described previously ${ }^{(7)}$.

Juvenile period: experiment 2. The larval period was followed by an intermediate period of 1 month (day 46 to day 77), during which the four groups were separately held at $19^{\circ} \mathrm{C}$ and fed a commercial diet with $2.7 \% \mathrm{EPA}+\mathrm{DHA}$ (DM basis), corresponding to the mean between the $\mathrm{XH}$ (3.7\% EPA + DHA) and HH (1.7\% EPA + DHA) diets. The four experimental groups were $\mathrm{XH} 2, \mathrm{HH} 2, \mathrm{LH} 2$ and XLH2. The day 77 juveniles of each group were anaesthetised (ethylene-glycol-monophenylether, $0 \cdot 15 \%$ ) and selected fish were randomly distributed in 60 litre square tanks (180 fish per tank). The fish were acclimatised to the experimental unit for $6 \mathrm{~d}$ (day 77 to day 83 ) at $19^{\circ} \mathrm{C}$, and two experimental isolipidic and isoproteic diets differing in their $n-3$ HUFA content by the incorporation of either rapeseed oil or cod-liver oil (Table 2) were progressively introduced. Four replicate groups per initial condition were fed the experimental $n$-3 HUFA-restricted diet $(0.3 \% \mathrm{EPA}+\mathrm{DHA})$, termed 'R-groups' $\left(\mathrm{XH} 2_{\mathrm{R}}, \mathrm{HH} 2_{\mathrm{R}}, \mathrm{LH} 2_{\mathrm{R}}\right.$ and $\mathrm{XLH} 2_{\mathrm{R}}$ ). Two other replicated groups per initial condition were fed an $n$-3 HUFA-rich diet (1.4\% EPA + DHA, i.e. 2fold higher than the $0.7 \% \mathrm{EPA}+\mathrm{DHA}$ requirement defined for sea bass juveniles ${ }^{(9)}$ and used as control 'C-groups' $\left(\mathrm{XH} 2_{\mathrm{C}}, \mathrm{HH} 2_{\mathrm{C}}, \mathrm{LH} 2_{\mathrm{C}}\right.$ and $\left.\left.\mathrm{XLH} 2_{\mathrm{C}}\right)\right)$. The rearing conditions of juveniles were as described previously ${ }^{(8)}$. The experiment started when all groups were fed entirely on the HUFArestricted or -rich diets (day 83, i.e. t0), and lasted until the final weights of all fish were increased at least 2-fold (day 118; i.e. $\mathrm{t} 35$ ).
Table 1. Formulation $(\mathrm{g} / 100 \mathrm{~g})$, chemical composition and fatty acid composition of total lipids (\% fatty acid methyl esters) of the four experimental larval diets differing in their highly unsaturated fatty acid (HUFA) content used in the larval experiment (experiment 1)

\begin{tabular}{|c|c|c|c|c|}
\hline Larval diet... & $\mathrm{XH}$ & $\mathrm{HH}$ & LH & $\mathrm{XLH}$ \\
\hline \multicolumn{5}{|l|}{ Ingredients* } \\
\hline Fish meal LT 94 & 11 & 11 & 11 & 11 \\
\hline Defatted fish meal & 41 & 41 & 41 & 41 \\
\hline CPSP 90 & 11 & 11 & 11 & 11 \\
\hline Soya oil & 0 & 0 & 1 & 1 \\
\hline Soya lecithin & 7 & 16 & 21 & 23 \\
\hline Marine lecithin LC 40 & 19 & 9 & 2 & 0 \\
\hline Vitamin mixture $†$ & 7 & 7 & 7 & 7 \\
\hline Mineral mixture $\ddagger$ & 3 & 3 & 3 & 3 \\
\hline Betaine & 1 & 1 & 2 & 2 \\
\hline Cellulose & 1 & 1 & 1 & 1 \\
\hline \multicolumn{5}{|l|}{ Chemical composition } \\
\hline DM (\%) & 91.4 & 91.0 & $90 \cdot 3$ & $90 \cdot 7$ \\
\hline Crude protein (\% DM) & 63.9 & $59 \cdot 2$ & $57 \cdot 0$ & $57 \cdot 1$ \\
\hline Crude fat (\% DM) & $18 \cdot 5$ & $19 \cdot 1$ & 19.9 & $20 \cdot 2$ \\
\hline Ash (\% DM) & 13.9 & $13 \cdot 9$ & $14 \cdot 0$ & 13.9 \\
\hline$n-3$ HUFA (\% DM) & $3 \cdot 8$ & $1 \cdot 8$ & 0.8 & 0.5 \\
\hline $\mathrm{EPA}+\mathrm{DHA}(\% \mathrm{DM})$ & $3 \cdot 7$ & $1 \cdot 7$ & 0.7 & 0.5 \\
\hline \multicolumn{5}{|c|}{ Fatty acid composition of total lipids } \\
\hline $18: 2 n-6$ & $18 \cdot 6$ & $35 \cdot 2$ & $44 \cdot 6$ & $47 \cdot 2$ \\
\hline $18: 3 n-6$ & 0.1 & 0.3 & 0.1 & $0 \cdot 2$ \\
\hline $20: 4 n-6$ & $1 \cdot 7$ & 0.8 & 0.5 & 0.2 \\
\hline $18: 3 n-3$ & 1.9 & $3 \cdot 3$ & $4 \cdot 1$ & $4 \cdot 4$ \\
\hline $20: 5 n-3$ & $9 \cdot 1$ & $4 \cdot 7$ & $2 \cdot 2$ & 1.7 \\
\hline $22: 6 n-3$ & $20 \cdot 5$ & $9 \cdot 8$ & 3.9 & $2 \cdot 2$ \\
\hline$\Sigma$ SFA & $27 \cdot 5$ & $26 \cdot 1$ & 24.9 & $24 \cdot 1$ \\
\hline$\Sigma$ MUFA & $18 \cdot 5$ & $18 \cdot 1$ & $18 \cdot 7$ & $18 \cdot 7$ \\
\hline$\sum n-6$ & $20 \cdot 8$ & $36 \cdot 7$ & 45.4 & $48 \cdot 0$ \\
\hline$\sum n-3$ & 32.9 & $19 \cdot 0$ & $11 \cdot 0$ & $9 \cdot 2$ \\
\hline
\end{tabular}

XH, extra-high-HUFA diet; HH, high-HUFA diet; LH, low-HUFA diet; XLH, extralow-HUFA diet.

*Sources: fish meal LT 94, Norse (Fyllingsdalen, Norway); hydrolysed fish meal, Archimex (Vannes, France); fish protein hydrolysate CPSP 90, Sopropêche (Boulogne sur Mer, France); soya oil, Système U (Créteil, France); soya lecithin, Louis François (Saint-Maur, France); marine lecithin LC 60, Phosphotech (SaintHerblain, France).

† Vitamin mixture contained ( $\mathrm{g} / \mathrm{kg}$ vitamin $\mathrm{mix}$ ): retinyl acetate, 1 ; cholecalciferol, 2.5; DL- $\alpha$-tocopheryl acetate, 5 ; menadione, 1 ; thiamine- $\mathrm{HCl}, 0.1$; riboflavin, 0.4 ; D-calcium pantothenate, 2; pyridoxine- $\mathrm{HCl}, 0.3$; cyanocobalamin, 1 ; niacin, 1 ; choline, 200; ascorbic acid (ascorbyl polyphosphate), 5; folic acid, 0.1; D-biotin, 1; meso-inositol, 30.

¥ Mineral mixture contained $\left(\mathrm{g} / \mathrm{kg}\right.$ mineral mix): $\mathrm{KCl}, 90 ; \mathrm{KI}, 0.04 ; \mathrm{CaHPO}_{4} \cdot 2 \mathrm{H}_{2} \mathrm{O}$, $500 ; \mathrm{NaCl}, 40 ; \mathrm{CuSO}_{4} .5 \mathrm{H}_{2} \mathrm{O}, 3 ; \mathrm{ZnSO}_{4} .7 \mathrm{H}_{2} \mathrm{O}, 4 ; \mathrm{CoSO}_{4}, 0.02 ; \mathrm{FeSO}_{4} .7 \mathrm{H}_{2} \mathrm{O}, 20$; $\mathrm{MnSO}_{4} \cdot \mathrm{H}_{2} \mathrm{O}, 3 ; \mathrm{CaCo}_{3}, 215 ; \mathrm{MgOH}, 124 ; \mathrm{Na}_{2} \mathrm{SeO}_{3}, 0.03 ; \mathrm{NaF}, 1$.

\section{Sampling procedures}

Experiment 1. For larval growth assessment and lipid composition, samplings were performed on $12 \mathrm{~h}$ fasted larvae at day 45 , corresponding to the end of the larval period (when all enzymic and molecular functions are established). For molecular analyses, intermediate samplings were also performed at day 10, day 17 and day 25 .

Weight was monitored by sampling thirty larvae in four tanks per condition (120 larvae per condition; $n 4)$. After a minimum preservation period of 3 weeks in $4 \%$ seawater formalin, larvae were individually weighed, pooled and dried for $24 \mathrm{~h}$ at $105^{\circ} \mathrm{C}$ to estimate the dry weight of each group $(n 4)$. Final biomass $(\mathrm{mg} / \mathrm{l})$ was the larvae mean wet weight per survival rate at day 45 ( $n 6$ for $\mathrm{XLH} l$ and $\mathrm{LH} 1$ and $n 4$ for $\mathrm{XH} 1$ and $\mathrm{HH}$ l). The survival rate was the ratio of the final to initial number of larvae in each tank, minus the number of larvae sampled ( $n 6$ for XLH1 and LH1 and $n 4$ for XH1 and HH 1 ). 
Table 2. Formulation $(\mathrm{g} / 100 \mathrm{~g})$, chemical composition and fatty acid composition of total lipids (\% fatty acid methyl esters) of the experimental highly unsaturated fatty acid (HUFA)-restricted diet and the HUFA control diet used in the juvenile experiment (experiment 2)

\begin{tabular}{|c|c|c|}
\hline & Restricted diet & Control diet \\
\hline \multicolumn{3}{|l|}{ Ingredients* ${ }^{\star}$} \\
\hline Lupin without pellicle & 50 & 50 \\
\hline Fish meal LT 94 & 12 & 12 \\
\hline Defatted fish meal & 8 & 8 \\
\hline Wheat amygluten 110 & 7 & 7 \\
\hline Fish hydrolysate CPSP 90 & 8 & 8 \\
\hline Vitamin mixture $†$ & 1 & 1 \\
\hline Mineral mixtureł & 1 & 1 \\
\hline Betaine & 0.5 & 0.5 \\
\hline Methionine & 0.2 & 0.2 \\
\hline Precooked starch & $3 \cdot 7$ & 3.7 \\
\hline Soya lecithin & 2 & 2 \\
\hline Rapeseed oil & $6 \cdot 6$ & 0 \\
\hline Cod-liver oil & 0 & $6 \cdot 6$ \\
\hline \multicolumn{3}{|l|}{ Chemical composition } \\
\hline DM (\%) & $92 \cdot 2$ & $92 \cdot 0$ \\
\hline Crude protein (\% DM) & $51 \cdot 8$ & $52 \cdot 2$ \\
\hline Crude fat (\% DM) & 14.9 & $15 \cdot 6$ \\
\hline Ash (\% DM) & 6.5 & $6 \cdot 5$ \\
\hline$n-3$ HUFA (\% DM) & 0.4 & 1.6 \\
\hline $\mathrm{EPA}+\mathrm{DHA}(\% \mathrm{DM})$ & 0.3 & 1.4 \\
\hline \multicolumn{3}{|c|}{ Fatty acids composition of total lipids } \\
\hline $18: 2 n-6$ & $20 \cdot 2$ & $11 \cdot 3$ \\
\hline $18: 3 n-6$ & 0.1 & 0.1 \\
\hline $20: 4 n-6$ & 0.1 & 0.3 \\
\hline $18: 3 n-3$ & 8.5 & $4 \cdot 3$ \\
\hline $20: 5 n-3$ & 1.2 & $4 \cdot 8$ \\
\hline $22: 6 n-3$ & 1.6 & $6 \cdot 1$ \\
\hline$\Sigma$ SFA & $13 \cdot 2$ & $17 \cdot 8$ \\
\hline$\Sigma$ MUFA & 54.3 & 52.5 \\
\hline$\sum n-6$ & $20 \cdot 7$ & $12 \cdot 3$ \\
\hline$\sum n-3$ & 11.9 & 17.5 \\
\hline
\end{tabular}

*Sources: lupin without pellicle, Le Gouessant ${ }^{\boxplus}$ aquaculture (Lamballe, France); fish meal LT 94, Norse (Fyllingsdalen, Norway); wheat amygluten 110, Chamtor Vitalor (Bazancourt, France); fish protein hydrolysate CPSP 90, Sopropêche (Boulogne sur Mer, France); precooked starch, Prégéflo Roquette frères (Lestrem, France)

†Vitamin mixture contained ( $\mathrm{g} / \mathrm{kg}$ vitamin mix): retinyl acetate, 1 ; cholecalciferol 2.5; DL- $\alpha$-tocopheryl acetate, 5 ; menadione, 1 ; thiamin- $\mathrm{HCl}, 0.1$; riboflavin, 0.4 D-calcium pantothenate, 2; pyridoxine- $\mathrm{HCl}, 0.3$; cyanocobalamin, 1; niacin, 1 ; choline, 200; ascorbic acid (ascorbyl polyphosphate), 5; folic acid, 0.1; D-biotin, 1 ; meso-inositol, 30 .

† Mineral mixture contained ( $\mathrm{g} / \mathrm{kg}$ mineral mix): $\mathrm{KCl}, 90 ; \mathrm{KI}, 0.04: \mathrm{CaHPO}_{4}, 2 \mathrm{H}_{2} \mathrm{O}$ $500 ; \mathrm{NaCl}, 40 ; \mathrm{CuSO}_{4} .5 \mathrm{H}_{2} \mathrm{O}, 3 ; \mathrm{ZnSO}_{4} .7 \mathrm{H}_{2} \mathrm{O}, 4 ; \mathrm{CoSO}_{4}, 0.02 ; \mathrm{FeSO}_{4} .7 \mathrm{H}_{2} \mathrm{O}, 20$; $\mathrm{MnSO}_{4} . \mathrm{H}_{2} \mathrm{O}, 3 ; \mathrm{CaCO}_{3}, 215 ; \mathrm{MgOH}, 124 ; \mathrm{Na}_{2} \mathrm{SeO}_{3}, 0.03 ; \mathrm{NaF}, 1$.

Measurement of the mRNA level of genes involved in digestive functions and lipid metabolism $(\Delta 6 \mathrm{D}$, and PPAR $\alpha$, PPAR $\beta$ and PPAR $\gamma$ ) was performed on $100 \mathrm{mg}$ of larvae at day 10 and day 17 and on about $300 \mathrm{mg}$ of larvae at day 25 and day 45, in four tanks per condition ( $n$ 4). Larvae were conserved in TRIzol reagent (Invitrogen, Carlsbad, CA, USA) (1 ml for $100 \mathrm{mg}$ of larvae) at $-80^{\circ} \mathrm{C}$ pending analysis.

For lipid analysis, fifty pooled larvae from each of four tanks per condition ( $n$ 4) were weighed and conserved at $-80^{\circ} \mathrm{C}$ pending analysis.

Experiment 2. Juveniles were anaesthetised before sampling (for all samplings, $n 4$ and $n 2$ for R- and C-groups, respectively). An $\mathrm{HH} 2_{\mathrm{C}}$ tank was lost at day 90 , resulting in $n 1$ for this group at day 90, day 104 and day 118 .

Growth was estimated by weighing individually fifty fish $( \pm 0 \cdot 1 \mathrm{~g})$ at day $83(\mathrm{t} 0)$, day $90(\mathrm{t} 7)$, day $104(\mathrm{t} 21)$ and day 118 (t35) in all tanks. The survival rate was estimated as for larvae. The daily growth index (DGI; \%) between t0 (day 83) and t35 (day 118) was calculated as follows:

$$
\text { DGI }_{\text {day } 83-118}=100 \times\left(\sqrt[3]{\mathrm{Wt}_{\text {day } 83}}-\sqrt[3]{\mathrm{Wt}_{\text {day } 118}}\right) \mathrm{d}^{-1} .
$$

Measurement of the mRNA level of genes involved in lipid metabolism $(\Delta 6 \mathrm{D}$ and $\operatorname{PPAR} \alpha, \beta$ and $\gamma$ ) was performed on $\mathrm{R}$-groups on ten pooled fish from each of four tanks per condition (forty fish per condition) at day 83, day 90, day 107 and day 118. They were immediately frozen in liquid $\mathrm{N}_{2}$ and stored at $-80^{\circ} \mathrm{C}$ until assayed.

Lipid analyses were performed on C- and R-groups. Six pooled fish per tank were taken at day 83 and ten pooled fish per tank were taken at day 118 . They were individually weighed, frozen in liquid $\mathrm{N}_{2}$ and stored at $-80^{\circ} \mathrm{C}$ pending analysis.

\section{Analytical methods}

Gene expression. Expression of $\Delta 6 \mathrm{D}$ and PPAR $\alpha, \operatorname{PPAR} \beta$ and PPAR $\gamma$ genes was performed on the whole body for larvae and on the liver for juveniles. Dissections of frozen juveniles were conducted on a glass plate maintained at $0^{\circ} \mathrm{C}$. The whole liver was isolated and the gall bladder removed because bile can destroy RNA. Gene expression measurements of each sample were performed on $200 \mathrm{mg}$ of homogenised pooled livers (Polytron ${ }^{\circledR}$ PT 2100 Bioblock ${ }^{\circledR}$; Fisher Bioblock Scientific, Illkirch, France). Total RNA was extracted from total larvae and livers using TRIzol reagent (Invitrogen, Carlsbad, CA, USA). cDNA were obtained in duplicate from total RNA $(1 \mu \mathrm{g})$ using the Quantitect Reverse Transcription ${ }^{\circledR}$ kit with integrated removal of genomic DNA contamination (QIAGEN $^{\circledR}$ GmbH, Hilden, Germany). Real-time PCR was performed using the iCycler iQTM ${ }^{\circledR}\left(\right.$ Bio-Rad $^{\circledR}$ Laboratories Inc., Hercules, CA, USA) as described in our previous studies $^{(7,8)}$. The specificity of forward and reverse primers for each gene was checked by sequencing the amplicon (Eurogentec, Labège, France). Primers for $\Delta 6 \mathrm{D}, \operatorname{PPAR} \alpha$ and PPAR $\beta$ were as described previously ${ }^{(7)}$. Those for PPAR $\gamma$ were $5^{\prime}-3^{\prime}$ : CAGATCTGAGGGCTCTGTCC and $3^{\prime}-5^{\prime}$ : CCTGGGTGGGTATCTGCTTA. Real-time PCR efficiencies (E) were determined for each gene from the given slopes in Bio-Rad ${ }^{\circledR}$ software (iCycler $\mathrm{iQ}^{\mathrm{TM}}$ Real-Time Detection System Software; Bio-Rad ${ }^{\circledR}$ Laboratories Inc., Hercules, CA, USA), according to equation 1 :

$$
\mathrm{E}=10^{(-1 / \text { slope })} \text {. }
$$

To determine the relative quantity of target gene-specific transcripts present in the different samples, expression ratios were calculated according to equation 2 :

$$
\begin{aligned}
\text { Ratio }= & \left(\left(E_{\text {gene }}\right)^{\Delta \mathrm{CT} \text { target gene (mean control }- \text { mean sample })}\right) / \\
& \left(\left(\mathrm{E}_{\mathrm{EF} 1}\right)^{\Delta \mathrm{CT} \text { EF1 (mean control }- \text { mean sample })}\right),
\end{aligned}
$$

where E is the PCR efficiency, 'mean sample' corresponds to the triplicate average and CT is the cycle threshold. The HH 1 and $\mathrm{HH} 2$ samples were used as the standard group for larval and juvenile experiments, respectively, because they are close to the rearing condition in fish farming. Elongation factor $1 \alpha$ 
$(E F 1 \alpha)$ was used as the reference gene ${ }^{(10)}$ as its expression is constant during the activation and proliferation of cells ${ }^{(11)}$.

\section{Fatty acid composition}

Whole frozen larvae were homogenised at $0^{\circ} \mathrm{C}$ using a Polytron ${ }^{\circledR}$ (PT 2100 Bioblock ${ }^{\circledR}$; Fisher Bioblock Scientific), while whole frozen juvenile were homogenised rapidly with a Hobart ${ }^{\circledR}$ mixer (Hobart Food Equipment Australia, Silverwater, NSW, Australia) in order to keep a low temperature and then, more accurately using a Polytron ${ }^{\circledR}$ (PT 2100 Bioblock ${ }^{\circledR}$; Fisher Bioblock Scientific). Lipid analyses were performed on a representative portion (about $1 \mathrm{~g}$ and about $5 \mathrm{~g}$ for larvae and juvenile samples, respectively) and about $3 \mathrm{~g}$ were taken for dry weight measurement $\left(105^{\circ} \mathrm{C} ; 24 \mathrm{~h}\right)$. Assays were conducted on one larval sample, while for juveniles they were performed on duplicates at day 83 and at day 118 .

Extraction of total lipid (TL), separation of neutral lipid (NL) and PL, preparation of fatty acid methyl esters (FAME) and separation of FAME were performed on larvae and juveniles as described in our previous study ${ }^{(7,8)}$. Each chromatogram was visually controlled on the computer using an amplification of the baseline in order to check the peak shape and quality of integration by the computer program. Internal standard (tricosanoic acid; 23:0) was used to quantify FAME in TL and NL on a fish fresh matter basis, and was added to a weighed known quantity of larvae before the TL extraction, while it was added before the TL and PL FAME extraction for juvenile lipid analysis. The results of individual fatty acid compositions were expressed as percentage of total identified FAME.

Chemical analyses of feed were performed in duplicate for each sample according to Association of Analytical Chemists $^{(12)}$ methods.

\section{Statistical analysis}

The data are presented as mean values with their standard errors of the replicate groups. Before applying statistical tests using Statistica ${ }^{\circledR}$ (Tulsa, OK, USA), percentage data were transformed by arcsine square root, and data for body weight, biomass and relative gene expression ratio were transformed by Ln. The effect of diet on growth performances, mRNA level for each sampling date and lipid composition was tested on means per tank using a one-way ANOVA, after control of equality of variances using Levene's test. Effects of diet and age of fish on mRNA level were tested on means per tank using two-way ANOVA, after control of equality of variances using the $\chi^{2}$ test. The effect of larval nutritional conditioning on mass gain of R-groups of juveniles, as well as between R- and C-groups was tested comparing curve slopes between $\mathrm{t} 0$ and $\mathrm{t} 7, \mathrm{t} 7$ and $\mathrm{t} 21$, and $\mathrm{t} 21$ and $\mathrm{t} 35$ by a one-way ANOVA. The Newman-Keuls multiple-range test was used to compare means in case of a significant effect $(P<0 \cdot 05)$.

\section{Results}

\section{Experiment 1}

Growth performances. Diet did not significantly influence larval survival rate $(46.0$ (SE 2.3) \%), while the mean wet weight was more than $25 \%$ higher in $\mathrm{XH} 1$ and $\mathrm{HH} 1$ groups than in LH 1 and XLH 1 groups (Fig. 1 (A); $P<0 \cdot 001$ ). The mean final biomass of XLH1 groups (892 (SE 108) mg/l) was about $34 \%$ lower than that of $\mathrm{XH} 1$ and $\mathrm{HH} 1$ groups (1367 (SE 47) $\mathrm{mg} / \mathrm{l} ; P<0.01$ ), while biomass measured in LH1 groups (1093 (SE 93) mg/l) was not significantly different from the others (Fig. 1 (B)).

Gene expression. At day 10 , the $\Delta 6 \mathrm{D}$ mRNA level was similar in all groups (Fig. 2 (A); 1.0 (SE 0.2)). At day 17, LH1 and XLH1 groups exhibited higher values than $\mathrm{XH} 1$ groups $(P<0.05)$ but were similar to $\mathrm{HH} 1$ groups. The difference between groups fed a low-HUFA diet (XLH1, LH 1$)$ and those fed a rich-HUFA diet $(\mathrm{XH} 1, \mathrm{HH} 1)$ increased with time, and mean $\Delta 6 \mathrm{D}$ mRNA level measured in XLH1 and $\mathrm{LH} 1$ groups was higher than that of $\mathrm{XH}$ l and $\mathrm{HH}$ l groups at day $45(P<0 \cdot 01)$.

One-way ANOVA analysis revealed that PPAR $\alpha, \beta$ and $\gamma$ mRNA levels were not affected by diet from day 10 to day 25 (Figs. 3 (A), 4 (A) and 5 (A)). At day 45, PPAR $\alpha$ and $\beta$ mRNA levels were higher in XLH1 groups than in others $(P<0.05)$, while PPAR $\gamma$ mRNA level was higher in XLH1 groups than that measured in LH 1 larvae $(P<0 \cdot 05)$ but similar to that measured in $\mathrm{XH} 1$ and $\mathrm{HH} 1$ groups.

Lipid analysis. The TL content in day 45 larvae was low (between 2 and $3 \%$ wet weight) and there were no significant differences between treatments (Table 3). Differences in NL
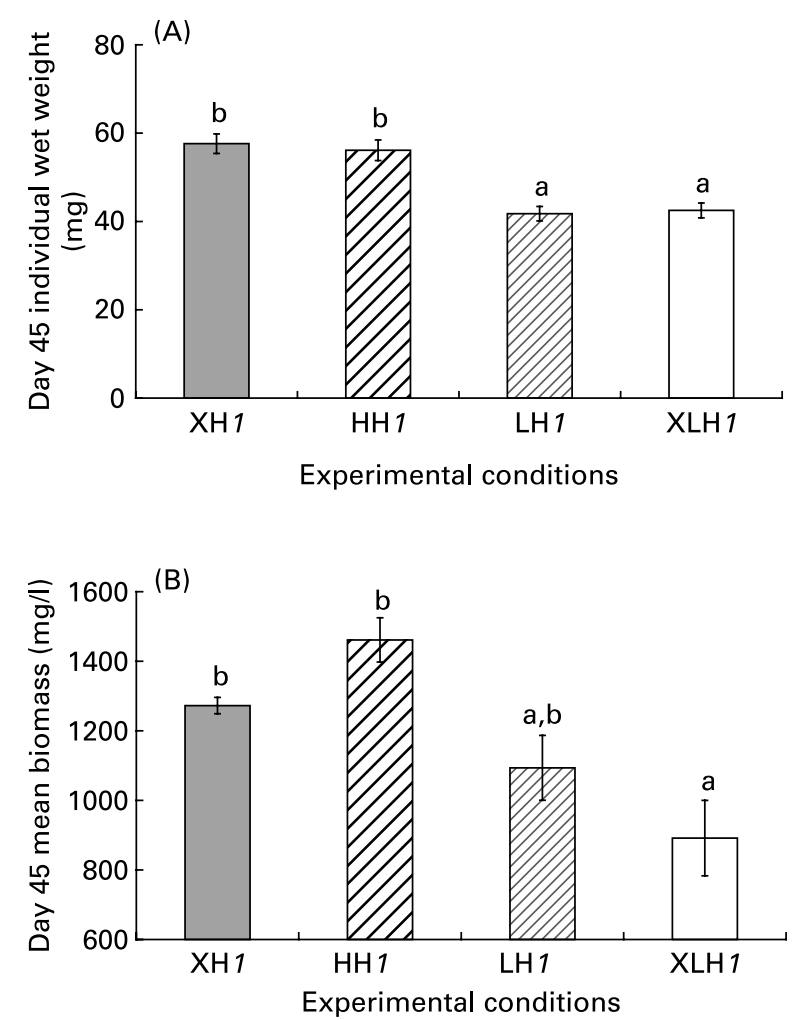

Fig. 1. (A) Day 45 mean larval wet weight $(n 4)$ and (B) biomass for each experimental condition ( $n 4$ for extra-high-highly unsaturated fatty acid (HUFA) (XH1) and high-HUFA (HH1) groups and $n 6$ for extra-low HUFA (XLH1) and low-HUFA (LH1) groups). Values are means, with their standard errors represented by vertical bars. The effect of diet was statistically significant $(P<0.01) .{ }^{a, b}$ Mean values with unlike letters were significantly different $(P<0.05)$. 

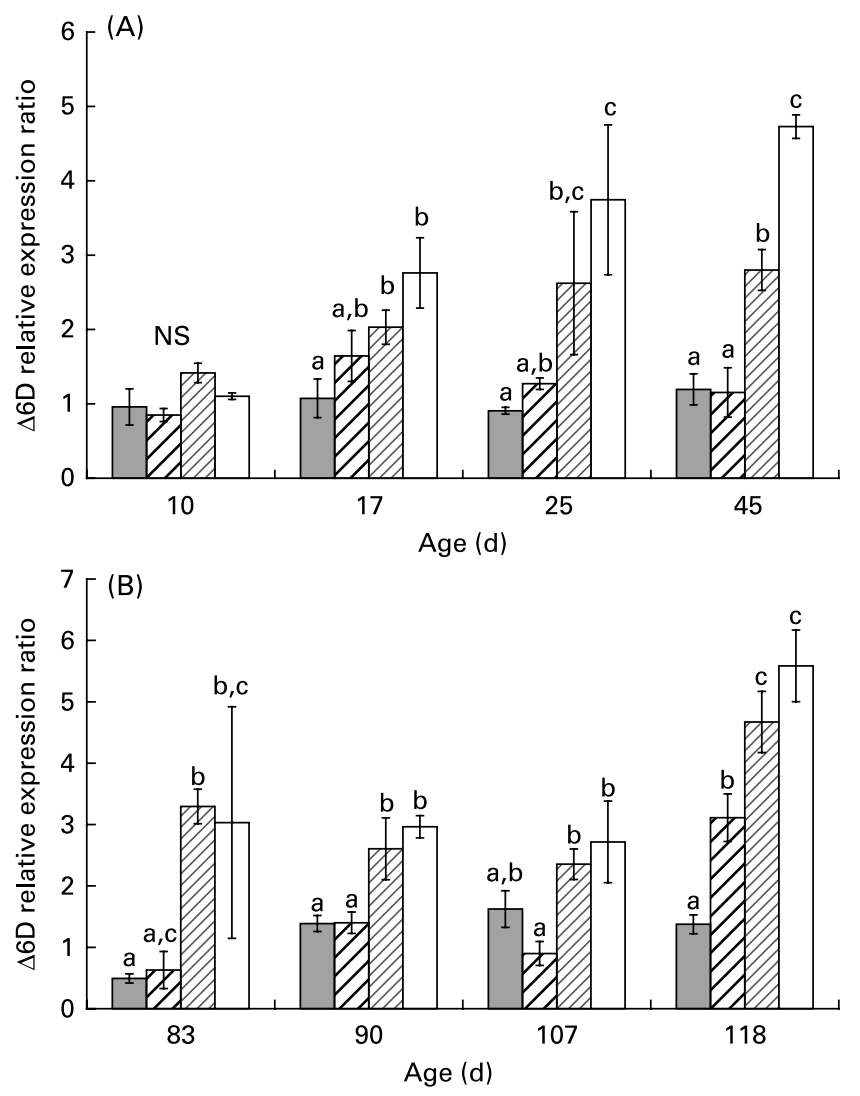

Fig. 2. (A) $\Delta-6$-Desaturase gene expression ratio $(\Delta 6 \mathrm{D})$ according to time in the larval experiment (experiment 1$)$ and for each experimental condition (n 4). ( $\square$ ), Extra-high-highly unsaturated fatty acid (HUFA) diet (XH1); ( $\square$ ), high-HUFA diet (HH1); (四), low-HUFA diet (LH1); ( $\square$ ), extra-low-HUFA diet (XLH1). Ratios are expressed relative to the $\mathrm{HH} 1$ group. (B) $\Delta 6 \mathrm{D}$ gene expression ratio according to time in the juvenile experiment (experiment 2; restricted-HUFA diet during the juvenile stage) and for each experimental condition ( $n$ 4). ( $\square$ ), Extra-high-highly unsaturated fatty acid (HUFA) larval diet $\left(\mathrm{XH} 2_{\mathrm{R}}\right) ;(\Xi)$, high-HUFA larval diet $\left(\mathrm{HH} 2_{\mathrm{R}}\right) ;(\Xi)$, low-HUFA larval diet $\left(\mathrm{LH} 2_{\mathrm{R}}\right) ;(\square)$, extra-low-HUFA larval diet $\left(\mathrm{XLH} 2_{\mathrm{R}}\right)$. Ratios are expressed relative to the $\mathrm{HH} 2_{\mathrm{R}}$ group. Values are means, with their standard errors represented by vertical bars. ${ }^{a, b, c}$ Mean values at a time point with unlike letters were significantly different $(P<0.05)$.

composition of larvae at day 45 reflected those of the diets (Tables 1 and 3). However, 18:3n-6 was significantly higher in the NL of XLH 1 and $\mathrm{LH} 1$ larvae than in the NL of $\mathrm{XH} l$ and $\mathrm{HH} l$ larvae $(P<0 \cdot 01)$ independent of $18: 3 n-6$ dietary content. HUFA (arachidonic acid (AA; 20:4n-6), EPA and DHA) contents were high in the PL of day 45 larvae, and increased from $\mathrm{XLH} 1$ to $\mathrm{XH} 1$, according to diet $(P<0 \cdot 05)$. The $18: 2 n-6$ and $18: 3 n-3$ contents were lower in the PL of larvae than in diets, and decreased from XLH1 to $\mathrm{XH} 1$, according to diet $(P<0 \cdot 001)$. Other PUFA were low and not directly related to diet composition: $18: 3 n-6$ and $20: 3 n-6$ were significantly higher in the PL of LH1 and $\mathrm{XLH} 1$ larvae than in the $\mathrm{PL}$ of $\mathrm{XH} 1$ and $\mathrm{HH} 1$ larvae $(P<0.001$ and $P<0 \cdot 0 \cdot 05$, respectively) and 20:2n-6 was lower in the PL of XH1 larvae than in the PL of other groups $(P<0 \cdot 001)$. The other intermediates in $n-3$ fatty acid synthesis $(18: 4 ; 20: 3,20: 4)$ were very low $(0 \cdot 12 ; 0.06$ and $0.20 \%$ of FAME, respectively) and their content was not different between the groups (data not presented in Table 3).
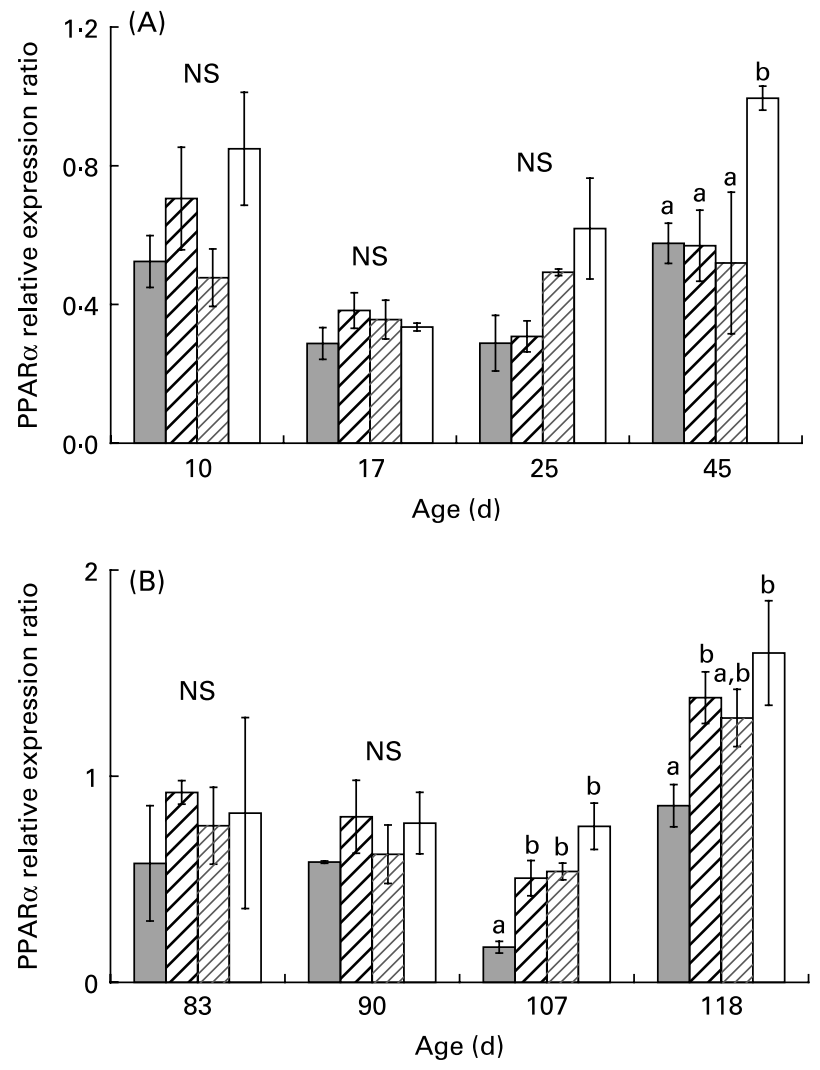

Fig. 3. (A) PPAR $\alpha$ expression ratio according to time in the larval experiment (experiment 1) and for each experimental condition ( $n$ 4). ( $\square$ ), Extra-highhighly unsaturated fatty acid (HUFA) diet (XH1); ( $\square)$, high-HUFA diet $(\mathrm{HH} 1)$; ( $\square$ ), low-HUFA diet (LH1); ( $\square$ ), extra-low-HUFA diet (XLH1). Ratios are expressed relative to the $\mathrm{HH} 1$ group. (B) PPAR $\alpha$ expression ratio according to time in the juvenile experiment (experiment 2; restricted-HUFA diet during the juvenile stage) and for each experimental condition ( $n$ 4). ( $\square$ ), Extra-highhighly unsaturated fatty acid (HUFA) larval diet $\left(\mathrm{XH}_{\mathrm{R}}\right)$; $(\square)$, high-HUFA larval diet $\left(\mathrm{HH}_{\mathrm{R}}\right)$; $(\square)$, low-HUFA larval diet $\left(\mathrm{LH} 2_{\mathrm{R}}\right) ;(\square)$, extra-low-HUFA larval diet $\left(\mathrm{XLH} 2_{\mathrm{R}}\right)$. Ratios are expressed relative to the $\mathrm{HH} 2_{\mathrm{R}}$ group. Values are means, with their standard errors represented by vertical bars. ${ }^{a, b}$ Mean values at a time point with unlike letters were significantly different $(P<0.05)$.

The PL content in day 45 larvae represented a major proportion of TL ranging from 41 to $47 \%$, with a significantly higher value in $\mathrm{XH}$ l fish than in $\mathrm{LH} 1$ and $\mathrm{XLH}$ l groups $(P<0.05)$. Accordingly, TL fatty acid profiles of larvae (not presented here) showed intermediate percentages between those obtained in NL and PL.

\section{Experiment 2}

Growth performances. Juvenile survival rate (98.3 (SE 0.25) $\%)$ was not affected by larval nutritional conditioning. There was no significant difference in weight increase from day 83 (t0) to day 118 (t35) in the four R-groups (2.2 (SE 0.02) g). The mass gain was similar between the R-groups (Fig. 6) and C-groups (not presented) from t0 to $\mathrm{t} 7$ (NS differences in curve slopes). From $\mathrm{t} 7$ to $\mathrm{t} 21$, mass increase was significantly higher in the R-groups than in $\mathrm{C}$-groups $(P<0.01)$ and significantly lower from t21 to $\mathrm{t} 35(P<0 \cdot 01)$. Day 83 to day 118 DGI was not significantly different $(P=0.075)$ between the R- (1.13 (SE 0.02) \%) and C-groups (1.19 (SE 0.00) \%). 

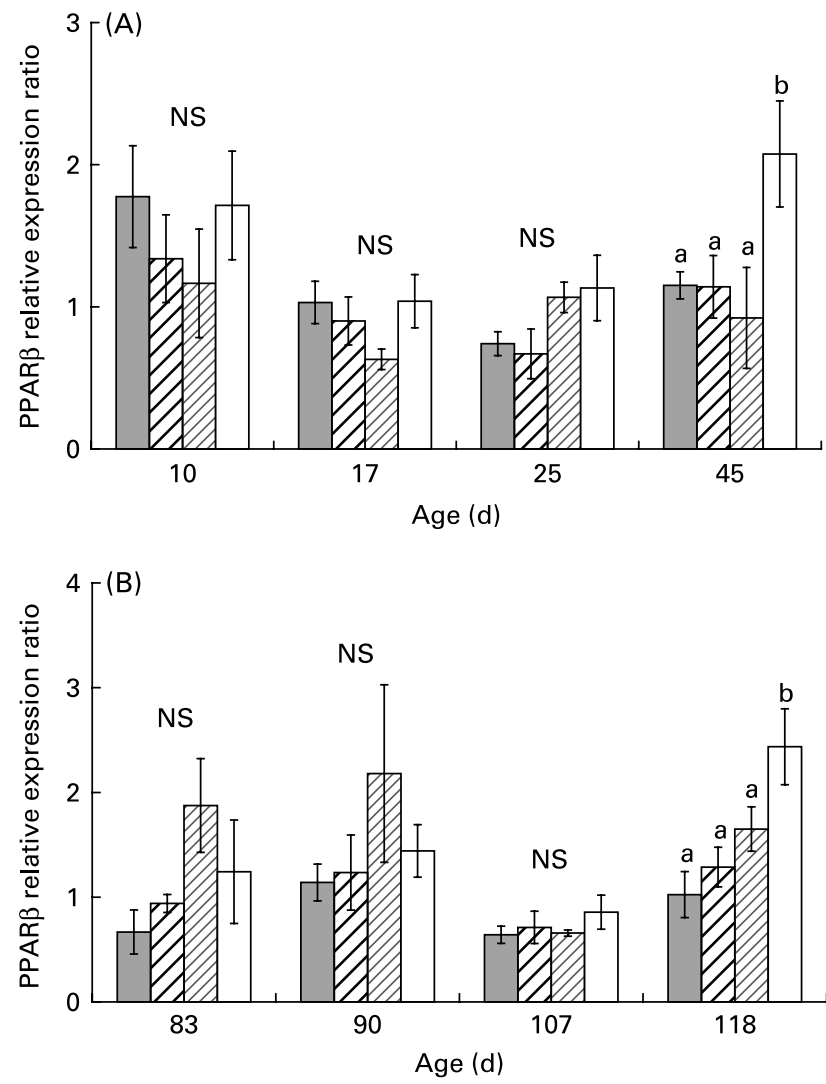

Fig. 4. (A) PPAR $\beta$ expression ratio according to time in the larval experiment (experiment 1) and for each experimental condition ( $n$ 4). ( $\square$ ), Extra-highhighly unsaturated fatty acid (HUFA) diet (XH1); ( $\square)$, high-HUFA diet $(\mathrm{HH} 1)$; (四), low-HUFA diet (LH1); ( $\square$ ), extra-low-HUFA diet (XLH1). Ratios are expressed relative to the $\mathrm{HH} 1$ group. (B) PPAR $\beta$ expression ratio according to time in the juvenile experiment (experiment 2; restricted-HUFA diet during the juvenile stage) and for each experimental condition ( $n 4)$. ( $\square$ ), Extra-highhighly unsaturated fatty acid (HUFA) larval diet $\left(\mathrm{XH}_{\mathrm{R}}\right)$; $(\square)$, high-HUFA larval diet $\left(\mathrm{HH} 2_{\mathrm{R}}\right) ;(\square)$, low-HUFA larval diet $\left(\mathrm{LH} 2_{\mathrm{R}}\right) ;(\square)$, extra-low-HUFA larval diet $\left(\mathrm{XLH} 2_{\mathrm{R}}\right)$. Ratios are expressed relative to the $\mathrm{HH} 2_{\mathrm{R}}$ group. Values are means, with their standard errors represented by vertical bars. ${ }^{a, b}$ Mean values at a time point with unlike letters were significantly different $(P<0.05)$.

Gene expression. The mean $\Delta 6 \mathrm{D}$ mRNA level was 2-fold higher at day 118 than at any time-point earlier (Fig. 2 (B); two-way ANOVA; $P<0 \cdot 001)$. One-way ANOVA performed at each sampling date indicated that $\Delta 6 \mathrm{D}$ mRNA level was significantly higher in $\mathrm{XLH} 2_{\mathrm{R}}$ and $\mathrm{LH} 2_{\mathrm{R}}$ groups than in $\mathrm{XH} 2_{\mathrm{R}}$ groups at day $83(P<0.05)$, while $\mathrm{XLH} 2_{\mathrm{R}}$ and $\mathrm{HH} 2_{\mathrm{R}}$ groups showed similar values. At day $90, \mathrm{XLH} 2_{\mathrm{R}}$ and $\mathrm{LH} 2_{\mathrm{R}}$ groups showed about 2-fold higher values than $\mathrm{XH} 2_{\mathrm{R}}$ and $\mathrm{HH} 2_{\mathrm{R}}$ groups $(P<0.05)$ and at day $107, \mathrm{XLH} 2_{\mathrm{R}}, \mathrm{LH} 2_{\mathrm{R}}$ and $\mathrm{XH} 2_{\mathrm{R}}$ groups showed higher values than in $\mathrm{HH} 2_{\mathrm{R}}$ groups $(P<0.05)$. At day 118 , the $\Delta 6 \mathrm{D}$ mRNA level was lowest in $\mathrm{XH} 2_{\mathrm{R}}$ groups $\left(1.4(\mathrm{SE} 0.2)\right.$ ) and highest in $\mathrm{XLH} 2_{\mathrm{R}}$ and $\mathrm{LH} 2_{\mathrm{R}}$ groups (4.7 (SE 0.5) and 5.6 (SE 0.6), respectively; $P<0.001)$.

The mean PPAR $\alpha$ and $\beta$ mRNA levels were globally higher at the end of experiment 2 (day 118) than at any previous timepoint (Figs. 3(B) and 4 (B); two-way ANOVA; $P<0.01$ ). Using one-way ANOVA, PPAR $\alpha$ and $\beta$ mRNA levels were similar in all R-groups at day 83 and day 90. At day 107, PPAR $\alpha$ mRNA level was about 3-fold lower in $\mathrm{XH} 2{ }_{\mathrm{R}}$ than in other groups $(P<0.01)$, while PPAR $\beta$ mRNA levels were similar in all groups. At day 118, PPAR $\alpha$ mRNA level was similar in $\mathrm{XH} 2_{\mathrm{R}}$ and $\mathrm{LH} 2_{\mathrm{R}}$ groups, and about $50 \%$ lower than in $\mathrm{HH} 2_{\mathrm{R}}$ and $\mathrm{XLH} 2_{\mathrm{R}}$ groups $(P<0.05)$. In comparison, PPAR $\beta$ was significantly higher in $\mathrm{XLH} 2_{\mathrm{R}}$ groups than in other groups $(P<0 \cdot 01)$. PPAR $\gamma$ mRNA level was significantly lower at day 107 than at other sampling periods (Fig. 5 (B); two-way ANOVA; $P<0.001)$. At day 83, it was more than 3fold higher in $\mathrm{LH} 2{ }_{\mathrm{R}}$ groups than in others (3.4 (SE 0.6); $P<0.05$ ), while non-significant differences occurred between groups at day 90 and day 107 . At day $118, \mathrm{XLH} 2_{\mathrm{R}}$ groups showed a significantly higher mRNA level than $\mathrm{XH} 2_{\mathrm{R}}$ and $\mathrm{HH} 2_{\mathrm{R}}$ groups $(P<0 \cdot 01)$.

Lipid analysis. The mean whole-body TL content of the R-groups was not significantly different between groups during the course of the experiment (Table 4). It was 4.4 (SE $0.4) \%$ wet weight at day 83 and 9.2 (SE 0.2) \% at day 118 . The PL content represented a higher proportion of TL at day 83 than at day $118(29.5$ (SE 1.1) v. 13.4 (SE 0.9) \% TL). At day 83 (i.e. after 1 month of feeding the commercial diet), the influence of diets observed during the larval stage disappeared, fatty acid composition was very similar in all groups, except for DHA,
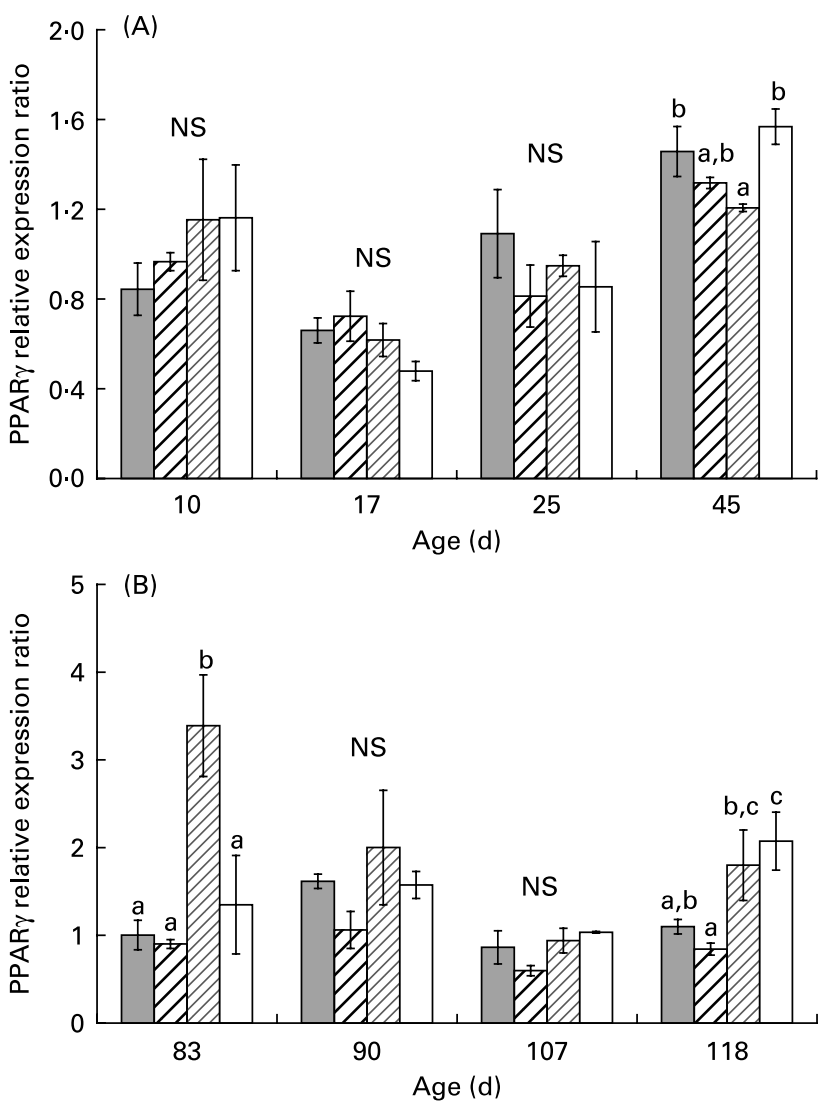

Fig. 5. (A) PPAR $\gamma$ expression ratio according to time in the larval experiment (experiment 1) and for each experimental condition ( $n$ 4). ( $\square$ ), Extra-highhighly unsaturated fatty acid (HUFA) diet (XH1); ( $)$ ), high-HUFA diet $(\mathrm{HH} 1)$; $(\square)$, low-HUFA diet (LH1); $\square$ ), extra-low-HUFA diet (XLH1). Ratios are expressed relative to the $\mathrm{HH} 1$ group. (B) PPAR $\gamma$ expression ratio according to time in the juvenile experiment (experiment 2; restricted-HUFA diet during the juvenile stage) and for each experimental condition ( $n 4)$. ( $\square$ ), Extra-highhighly unsaturated fatty acid (HUFA) larval diet $\left(\mathrm{XH}_{\mathrm{R}}\right) ;(\square)$, high-HUFA larval diet $\left(\mathrm{HH} 2_{\mathrm{R}}\right) ;(\square)$, low-HUFA larval diet $\left(\mathrm{LH} 2_{\mathrm{R}}\right) ;(\square)$, extra-low-HUFA larval diet $\left(\mathrm{XLH} 2_{\mathrm{R}}\right)$. Ratios are expressed relative to the $\mathrm{HH} 2_{\mathrm{R}}$ group. Values are means, with their standard errors represented by vertical bars. ${ }^{a, b, c}$ Mean values at a time point with unlike letters were significantly different $(P<0.05)$. 
Table 3. Total lipid content, polar lipid content and fatty acid profiles (\% fatty acid methyl esters) of neutral lipids and polar lipids in day 45 larvae that had been fed four experimental larval diets differing in their highly unsaturated fatty acid (HUFA) content (experiment 1)

(Mean values $(n 4)$ with their standard errors)

\begin{tabular}{|c|c|c|c|c|c|c|c|c|c|}
\hline \multirow{3}{*}{ Diet group... } & \multicolumn{8}{|c|}{ Day 45 larval composition } & \multirow[b]{3}{*}{ Statistical analysis } \\
\hline & \multicolumn{2}{|c|}{$\mathrm{XH} 1$} & \multicolumn{2}{|c|}{$\mathrm{HH} 1$} & \multicolumn{2}{|c|}{ LH1 } & \multicolumn{2}{|c|}{$\mathrm{XLH} 1$} & \\
\hline & Mean & $\mathrm{SE}$ & Mean & SE & Mean & $\mathrm{SE}$ & Mean & SE & \\
\hline Total lipids (\% wet weight) & $2 \cdot 3$ & 0.2 & 2.9 & 0.2 & 2.9 & 0.2 & $2 \cdot 7$ & 0.2 & NS \\
\hline Polar lipids (\% total lipids) & $47^{\mathrm{a}}$ & 4 & $44^{a, b}$ & 2 & $42^{b}$ & 0 & $41^{\mathrm{b}}$ & 1 & * \\
\hline \multicolumn{10}{|l|}{ Neutral lipids } \\
\hline $16: 0$ & $18 \cdot 9^{a}$ & 0.3 & $19 \cdot 2^{\mathrm{a}}$ & 0.2 & $17 \cdot 9^{b}$ & 0.2 & $17 \cdot 4^{\mathrm{b}}$ & 0.4 & 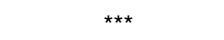 \\
\hline $18: 0$ & $4 \cdot 4^{\mathrm{a}}$ & 0.1 & $3 \cdot 9^{b}$ & 0.2 & $4 \cdot 4^{\mathrm{a}}$ & 0.2 & $4 \cdot 6^{\mathrm{a}}$ & 0.2 & $\star * \star *$ \\
\hline $18: 1$ & $0.2^{\mathrm{a}}$ & 0.1 & $0.2^{a, b}$ & 0.2 & $0 \cdot 1^{b}$ & 0.1 & $0.0^{\mathrm{b}}$ & 0.1 & * \\
\hline $18: 2 n-6$ & $18 \cdot 7^{\mathrm{a}}$ & 0.1 & $36 \cdot 0^{\mathrm{b}}$ & 0.1 & $43 \cdot 4^{c}$ & 0.2 & $44 \cdot 4^{d}$ & 0.3 & 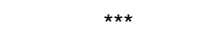 \\
\hline $18: 3 n-6$ & $0.2^{\mathrm{a}}$ & 0.0 & $0.1^{\mathrm{b}}$ & 0.0 & $0.5^{\mathrm{c}}$ & 0.0 & $0.9^{\mathrm{d}}$ & 0.1 & ** \\
\hline $20: 2 n-6$ & $1 \cdot 2^{\mathrm{a}}$ & 0.0 & $1.4^{\mathrm{b}}$ & 0.1 & $1 \cdot 3^{\mathrm{a}, \mathrm{b}}$ & 0.0 & $1 \cdot 2^{\mathrm{a}}$ & 0.1 & * \\
\hline $20: 4 n-6$ & $1.4^{\mathrm{a}}$ & 0.0 & $0.7^{\mathrm{b}}$ & 0.0 & $0.3^{c}$ & 0.0 & $0.2^{d}$ & 0.0 & $\star *$ \\
\hline $18: 3 n-3$ & $1.8^{\mathrm{a}}$ & 0.0 & $3 \cdot 1^{b}$ & 0.0 & $3.7^{\mathrm{c}}$ & 0.0 & $3 \cdot 8^{\mathrm{c}}$ & 0.1 & $* * *$ \\
\hline $18: 4 n-3$ & $0.5^{\mathrm{a}}$ & 0.0 & $0.4^{\mathrm{a}, \mathrm{b}}$ & 0.0 & $0.4^{a, b}$ & 0.0 & $0.4^{b}$ & 0.0 & * \\
\hline $20: 4 n-3$ & $0.4^{a}$ & 0.0 & $0.2^{\mathrm{b}}$ & 0.0 & $0.2^{\mathrm{b}}$ & 0.0 & $0.2^{b}$ & 0.0 & *** \\
\hline $20: 5 n-3$ & $7 \cdot 7^{\mathrm{a}}$ & 0.1 & $3.9^{b}$ & 0.1 & $1 \cdot 8^{\mathrm{C}}$ & 0.1 & $1 \cdot 1^{\mathrm{d}}$ & 0.0 & *** \\
\hline $22: 5 n-3$ & $0.7^{\mathrm{a}}$ & 0.0 & $0.5^{\mathrm{b}}$ & 0.0 & $0.3^{c}$ & 0.0 & $0.3^{\mathrm{c}}$ & 0.0 & $\star * \star *$ \\
\hline $22: 6 n-3$ & $18 \cdot 2^{\mathrm{a}}$ & 0.2 & $7 \cdot 3^{\mathrm{b}}$ & 0.2 & $2 \cdot 3^{\mathrm{c}}$ & 0.0 & $1.4^{\mathrm{d}}$ & 0.0 & *** \\
\hline$\Sigma$ Saturated & $26 \cdot 8^{a}$ & 0.2 & $25 \cdot 4^{b}$ & 0.2 & $24 \cdot 6^{\mathrm{C}}$ & 0.1 & $24 \cdot 4^{\mathrm{C}}$ & 0.1 & $* * *$ \\
\hline$\Sigma$ MUFA & $22 \cdot 2^{\mathrm{a}}$ & 0.1 & $20 \cdot 7^{\mathrm{c}}$ & 0.3 & $21 \cdot 1^{\mathrm{b}, \mathrm{c}}$ & 0.0 & $21 \cdot 4^{b}$ & 0.0 & $* * *$ \\
\hline$\Sigma$ PUFA & $51 \cdot 0^{\mathrm{a}}$ & 0.4 & $53 \cdot 9^{b}$ & 0.3 & $54 \cdot 3^{\mathrm{b}}$ & 0.3 & $54 \cdot 1^{\mathrm{b}}$ & 0.3 & $* * *$ \\
\hline \multicolumn{10}{|l|}{ Polar lipids } \\
\hline $16: 0$ & $22 \cdot 6^{a}$ & 0.2 & $21 \cdot 6^{b}$ & 0.2 & $20 \cdot 1^{\mathrm{c}}$ & 0.4 & $19 \cdot 8^{c}$ & 0.3 & 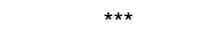 \\
\hline 18:0 & $6 \cdot 2^{\mathrm{a}}$ & 0.3 & $6 \cdot 6^{\mathrm{b}}$ & 0.1 & $7 \cdot 2^{\mathrm{c}}$ & 0.2 & $7 \cdot 5^{\mathrm{c}}$ & 0.1 & 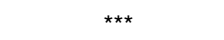 \\
\hline $18: 1$ & 0.1 & 0.0 & 0.1 & 0.0 & 0.1 & 0.0 & 0.1 & 0.1 & NS \\
\hline $18: 2 n-6$ & $8 \cdot 8^{a}$ & 0.1 & $22 \cdot 6^{b}$ & 0.1 & $34.9^{c}$ & 0.2 & $39.6^{d}$ & 0.2 & $* \star \star$ \\
\hline $18: 3 n-6$ & $0.0^{\mathrm{a}}$ & 0.0 & $0.2^{\mathrm{b}}$ & 0.1 & $0.3^{\mathrm{c}}$ & 0.1 & $0.5^{\mathrm{c}}$ & 0.0 & 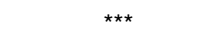 \\
\hline $20: 2 n-6$ & $1 \cdot 3^{\mathrm{a}}$ & 0.1 & $1 \cdot 7^{\mathrm{b}}$ & 0.1 & $1 \cdot 8^{\mathrm{b}}$ & 0.0 & $1.9^{b}$ & 0.0 & $\star \star \star *$ \\
\hline $20: 3 n-6$ & $0.1^{\mathrm{a}}$ & 0.0 & $0.1^{\mathrm{a}}$ & 0.0 & $0.2^{\mathrm{b}}$ & 0.0 & $0.2^{b}$ & 0.0 & * \\
\hline $20: 4 n-6$ & $3 \cdot 1^{\mathrm{a}}$ & 0.0 & $1.9^{b}$ & 0.0 & $1.0^{c}$ & 0.0 & $0.6^{\mathrm{d}}$ & 0.1 & $\star * *$ \\
\hline $18: 3 n-3$ & $0.5^{\mathrm{a}}$ & 0.0 & $1 \cdot 2^{b}$ & 0.0 & $1 \cdot 7^{\mathrm{c}}$ & 0.0 & $1.9^{d}$ & 0.0 & $* * *$ \\
\hline $20: 5 n-3$ & $9 \cdot 7^{\mathrm{a}}$ & 0.1 & $6 \cdot 8^{\mathrm{b}}$ & 0.0 & $4 \cdot 7^{\mathrm{c}}$ & 0.1 & $3.7^{d}$ & 0.1 & 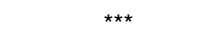 \\
\hline $22: 5 n-3$ & 0.5 & 0.0 & 0.6 & 0.0 & 0.6 & 0.0 & 0.6 & 0.0 & NS \\
\hline $22: 6 n-3$ & $33 \cdot 1^{\mathrm{a}}$ & 0.4 & $23 \cdot 5^{\mathrm{b}}$ & 0.2 & $13.5^{\mathrm{c}}$ & 0.2 & $9.2^{\mathrm{d}}$ & 0.1 & $\star \star \star \star *$ \\
\hline$\Sigma$ SFA & $29 \cdot 8^{a}$ & 0.3 & $29 \cdot 1^{a}$ & 0.1 & $28 \cdot 2^{b}$ & 0.3 & $28 \cdot 1^{\mathrm{b}}$ & 0.2 & ** \\
\hline$\Sigma$ MUFA & $12 \cdot 7^{\mathrm{a}, \mathrm{b}}$ & 0.3 & $12 \cdot 1^{\mathrm{a}}$ & 0.3 & $12 \cdot 6^{a, b}$ & 0.1 & $13 \cdot 0^{\mathrm{b}}$ & 0.0 & * \\
\hline$\Sigma$ PUFA & $57 \cdot 6^{a}$ & 0.7 & $58 \cdot 8^{b}$ & 0.3 & $59 \cdot 2^{b}$ & 0.4 & $58 \cdot 9^{b}$ & 0.3 & * \\
\hline
\end{tabular}

XH, extra-high-HUFA diet; HH, high-HUFA diet; LH, low-HUFA diet; XLH, extra-low-HUFA diet.

a,b,c,d Mean values within a row with unlike superscript letters were significantly different $(P<0.05)$.

${ }^{*} P<0.05,{ }^{* *} P<0.01,{ }^{* \star *} P<0.001$.

which was higher in the $\mathrm{NL}$ of $\mathrm{XH} 2{ }_{\mathrm{R}}$ groups than in others $(12 \cdot 4$ $(\operatorname{SE} 0.2)$ v. 11.5 (SE 0.0) \% FAME; $P<0.05)$. At day 118, the DHA, EPA, AA, $18: 3 n-6$ and SFA contents in the NL of R-groups were higher than in the restricted diet $(P<0.05)$, while $18: 2 n-6,18: 3 n-3$, MUFA and PUFA levels were lower (Tables 4 and 2). DHA, EPA and 20:3n-3 were higher in the $\mathrm{NL}$ of $\mathrm{XH} 22_{\mathrm{R}}$ groups than in others at day $118(P<0 \cdot 01$ and $P<0 \cdot 05$, respectively). Other fatty acids in NL were not significantly different within the R-groups. From day 83 to day 118 , $18: 2 n-6,18: 3 n-3$ and MUFA content in NL increased by 45 , 75 and $41 \%$, respectively, while other fatty acids, including DHA, EPA and AA decreased (11.9 (SE 0.2) v. 2.4 (SE 0.1) \% FAME for DHA). The $18: 3 n-6$, AA, EPA and DHA contents were higher in the PL of day 118 juveniles than in their restricted diet, while the contrary was observed for $18: 2 n-6$ and $18: 3 n-3$ (Table 4 and 2). From day 83 to day $118,18: 2 n-6,18: 3 n-6$, $20: 2 n-6,20: 3 n-6, \quad 18: 3 n-3$ and MUFA content in PL increased, while others fatty acids, including DHA, EPA and AA, decreased (Fig. 7). The fatty acid content in PL was not significantly different within the R-groups at day 83, as well as at day 118, except for $20: 4 n-3$, which was higher in $\mathrm{LH} 2_{\mathrm{R}}$ groups than in others $(P<0.05)$. The AA, EPA, DHA, SFA and PUFA were noticeably higher in PL than in NL at day 83 and day 118.

The fatty acid content of the C-groups was related to the control diet (not detailed here). Their HUFA content was clearly higher than in the R-groups (not detailed here). The AA, EPA and DHA contents in the PL of the C-groups were 1.9 (SE 0.0), 9.8 (SE 0.2) and 24.2 (SE 1.3) \% FAME, respectively. The low number of replicates did not allow a statistical evaluation within C-groups.

\section{Discussion}

The aim of the present study was to elucidate whether the stimulation of desaturation/elongation pathways for $n-3$ HUFA synthesis in juveniles induced by a larval nutritional conditioning shown in a previous study ${ }^{(8)}$ can be amplified 


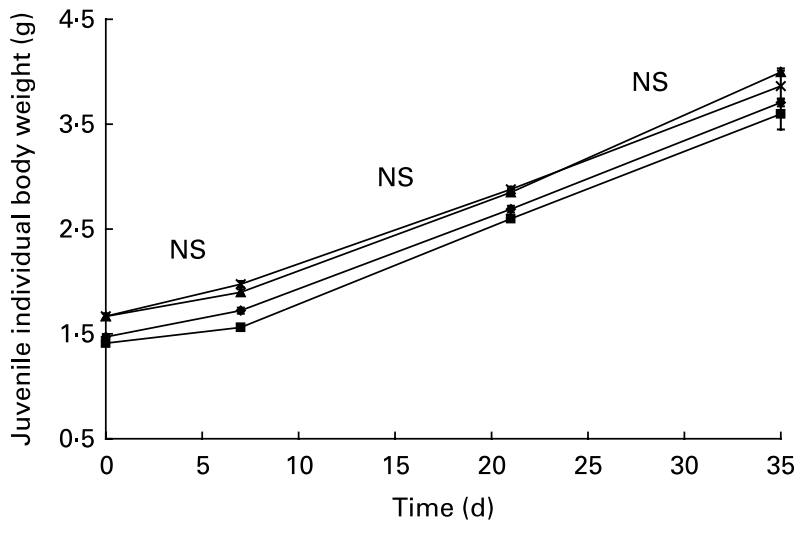

Fig. 6. Fresh body weight increase over time (days 83-118) in the juvenile experiment (experiment 2; restricted-HUFA diet during the juvenile stage) for the four restricted groups $(n 4) .(-\boldsymbol{\Lambda}-)$, Extra-high-highly unsaturated fatty acid (HUFA) larval diet $\left(\mathrm{XH}_{2}\right) ;(-\times-)$, high-HUFA larval diet $\left(\mathrm{HH} 2_{\mathrm{R}}\right) ;(-\bullet-)$, low-HUFA larval diet $\left(\mathrm{LH} 2_{\mathrm{R}}\right) ;(-\mathbf{-}-)$, extra-low-HUFA larval diet $\left(\mathrm{XLH} 2_{\mathrm{R}}\right)$. Values are means, with their standard errors represented by vertical bars.

using a large range of $n-3$ HUFA content (0.5-3.7\% $\mathrm{EPA}+\mathrm{DHA})$ in the larval diet and a severe $n-3$ HUFArestricted diet $(0.3 \% \mathrm{EPA}+\mathrm{DHA}$; restricted diet) during the juvenile period.

As encountered in other studies ${ }^{(7,13)}$, diet composition had no significant effect on larval survival rates, while very low dietary $n$-3 HUFA content (XLH; $0.5 \%$ EPA + DHA) led to decreased larval mass gain. Survival rates obtained were in agreement with a previous study ${ }^{(13)}$, in which sea bass larvae reared at $19^{\circ} \mathrm{C}$ and fed a diet similar to $\mathrm{HH} 1$ had a survival rate of $48 \%$ at day 38 . The effect of high dietary HUFA content on mass gain could be the consequence of an elevated $n$-3-HUFA requirement for high cellular turnover during the larval stage ${ }^{(14)}$. Larval mean weights obtained in the present study were high at day 45 , and the values obtained in $\mathrm{HH} 1$ groups was much higher than found previously ${ }^{(13)}$ in sea bass larvae reared in similar conditions. This could indicate that the initial larvae were of high quality. As previously observed $^{(8)}$, larval conditioning did not affect the growth performance of sea bass juveniles fed the restricted diet, despite large differences in juvenile initial weight at the onset of experiment 2 , as a result of the different $n-3$ HUFA contents of the larval diets. The weight increase of R-juveniles was good in all groups, as it more than doubled in $35 \mathrm{~d}$, and was not significantly different from that observed in C-groups during week 1 of the experiment. However, the growth of the R-groups seemed to be limited during the last period of the experiment. This was in accordance with a significant growth retardation of sea bass juveniles fed different HUFA dietary contents for 7 weeks $^{(9)}$.

As observed earlier ${ }^{(7,8)}$, the level of $\Delta 6 \mathrm{D}$ mRNA was significantly higher in larvae fed a restricted $n$-3 HUFA diet during the larval stage $(0.5$ or $0.7 \% \mathrm{EPA}+\mathrm{DHA})$ and in juveniles fed a low-HUFA diet ( $0.3 \%$ EPA + DHA) following a transient feeding on a HUFA diet. This revealed that (i) $\Delta 6 \mathrm{D}$ transcription could be modulated by the $n-3$ HUFA content of the diet, as observed in seabream ${ }^{(15)}$ and, that (ii) conditioned juveniles were better than unconditioned fish in better developing desaturation processes in order to adapt to a low dietary HUFA content. The mRNA expression data were supported by the significant increase in $18: 3 n-6$ measured in PL, as it is the $\Delta 6 \mathrm{D}$ desaturation product of $18: 2 n-6$, and could not have been obtained through the diet. These findings indicate that the increase in the level of $\Delta 6 \mathrm{D}$ mRNA probably led to an increase in $\Delta 6 \mathrm{D}$ enzymic activity required for the first step of the bioconversion of 18-carbon fatty acids to HUFA (20-22 carbons), and for the conversion of EPA to DHA ${ }^{(16)}$. Contrary to our previous study ${ }^{(8)}$, the present results showed a persistence of $\triangle 6 \mathrm{D}$ mRNA level in juveniles $30 \mathrm{~d}$ after feeding of the larval diets ceased, and beyond the intermediate period on a high-HUFA diet. It may be a consequence of (i) the more restricted HUFA contents in the larval $(0.5$ and $0.7 \% \mathrm{EPA}+\mathrm{DHA} v .0 .8 \%)$ and juvenile $(0.3 v \cdot 0.5 \%)$ diets used, (ii) the younger fish used (day $83 v$. day 151 at the beginning of experiment 2), or (iii) a shorter acclimatisation period (30 v. $90 \mathrm{~d})$.

The present results demonstrated that PPAR $\alpha$ and PPAR $\beta$ genes, which are involved in fatty acid catabolism and keratinocyte differentiation, showed a higher mRNA level in day 45 larvae fed the lowest dietary n-3 HUFA content $(0.5 \%$ $\mathrm{EPA}+\mathrm{DHA}$ ); this was maintained in day 118 juveniles in the case of PPAR $\beta$. These results were in concordance with the higher $\Delta 6 \mathrm{D}$ mRNA level measured in these groups at the same times. According to several studies conducted in mammals ${ }^{(17)}$, PPAR are involved, along with sterol regulatory element binding protein-1 (SREBP-1a and SREBP-1c), in the control of the $\Delta 6 \mathrm{D}$ gene transcription. SREBP-1 binds to sterol regulatory elements, and mediates the suppression of the $\Delta 6 \mathrm{D}$ gene by HUFA. In the present study, the concomitant increase of PPAR and $\triangle 6 \mathrm{D}$ mRNA levels suggested that PPAR could be partly involved in modulating $\Delta 6 \mathrm{D}$ gene expression in larval and juvenile sea bass. PPAR $\gamma$ is involved in adipocyte differentiation and induction of lipogenic enzymes and, although its mRNA level was not significantly higher in larvae fed an $n$-3 HUFA-deprived diet, it was significantly higher in day 118 juveniles pre-conditioned with the lowest- $n-3$ HUFA diet during the larval stage. This suggested that PPAR $\gamma$ could also have a role in the stimulation of the $\Delta 6 \mathrm{D}$ gene expression observed at the same time. The stimulation of PPAR mRNA level was not significantly higher in juveniles pre-conditioned with the LH diet (0.7\% HUFA dietary content), in spite of the significantly higher $\Delta 6 \mathrm{D}$ mRNA level measured in these groups. We could hypothesise that the $\Delta 6 \mathrm{D}$ gene could possibly be stimulated by PPAR when drastic nutritional conditions occurred, and that above a threshold, other mechanisms like those observed in mammals may be implicated, such as SREBP-1. This hypothesis is in concordance with previous results ${ }^{(8)}$, which did not reveal any significant stimulation of PPAR, using a conditioning larval diet containing $0.8 \% \mathrm{EPA}+\mathrm{DHA}$, while a higher $\Delta 6 \mathrm{D}$ mRNA level was observed.

As the increase in PPAR and $\triangle 6 \mathrm{D}$ mRNA levels observed in larvae fed a low-HUFA diet was retained in juveniles fed a low-HUFA diet, this indicated that (i) pre-conditioned fish were able to develop adaptation to low dietary HUFA content during the juvenile period and that (ii) this adaptation could be the consequence of nutritional programming occurring during larval stage. Several existing biological mechanisms described in mammals could explain the 'memory' of metabolic effects of early nutritional environments in juveniles ${ }^{(18)}$ : induced variations in organ structure, alterations in cell number, 
Table 4. Total lipid content, polar lipid content and fatty acid profiles (\% fatty acid methyl esters) of neutral lipids and polar lipids in day 118 restricted juveniles that had been fed during the larval stage four experimental diets differing in their highly unsaturated fatty acid (HUFA) content (experiment 2)

(Mean values $(n 4)$ with their standard errors)

\begin{tabular}{|c|c|c|c|c|c|c|c|c|c|}
\hline \multirow{3}{*}{ Diet group... } & \multicolumn{8}{|c|}{ Day 118 juveniles } & \multirow[b]{3}{*}{ Statistical analysis } \\
\hline & \multicolumn{2}{|c|}{$\mathrm{XH} 2_{\mathrm{R}}$} & \multicolumn{2}{|c|}{$\mathrm{HH} 2_{\mathrm{R}}$} & \multicolumn{2}{|c|}{$\mathrm{LH} 2 \mathrm{R}$} & \multicolumn{2}{|c|}{$\mathrm{XLH} 2_{\mathrm{R}}$} & \\
\hline & Mean & SE & Mean & $\mathrm{SE}$ & Mean & SE & Mean & SE & \\
\hline Total lipids (\% wet weight) & $9 \cdot 8$ & 0.6 & $8 \cdot 8$ & 0.2 & $8 \cdot 8$ & 0.5 & $9 \cdot 3$ & $0 \cdot 2$ & NS \\
\hline Polar lipids (\% total lipids) & 13.6 & 1.0 & $14 \cdot 2$ & 0.8 & 11.6 & 0.9 & $14 \cdot 1$ & 1.0 & NS \\
\hline \multicolumn{10}{|l|}{ Neutral lipids } \\
\hline $16: 0$ & $11 \cdot 4$ & 0.1 & $11 \cdot 8$ & 0.1 & $11 \cdot 4$ & 0.1 & 11.9 & 0.1 & NS \\
\hline $18: 0$ & 2.9 & 0.0 & 3.0 & 0.0 & 2.9 & 0.0 & 3.0 & 0.0 & NS \\
\hline $18: 1$ & 0.1 & 0.0 & 0.1 & 0.0 & 0.1 & 0.1 & 0.1 & 0.0 & NS \\
\hline $18: 2 n-6$ & $16 \cdot 2$ & 0.2 & $16 \cdot 6$ & 0.3 & $17 \cdot 0$ & 0.1 & $16 \cdot 8$ & 0.1 & NS \\
\hline $18: 3 n-6$ & 0.3 & 0.0 & 0.3 & 0.0 & 0.3 & 0.0 & 0.3 & 0.0 & NS \\
\hline $20: 2 n-6$ & 0.6 & 0.0 & 0.6 & 0.0 & 0.6 & 0.0 & 0.6 & 0.0 & NS \\
\hline $20: 3 n-6$ & 0.1 & 0.0 & 0.1 & 0.0 & 0.1 & 0.0 & 0.1 & 0.0 & NS \\
\hline $20: 4 n-6$ & 0.2 & 0.0 & 0.2 & 0.0 & 0.2 & 0.0 & 0.2 & 0.0 & NS \\
\hline $18: 3 n-3$ & $6 \cdot 2$ & 0.1 & $6 \cdot 3$ & 0.2 & $6 \cdot 5$ & 0.0 & $6 \cdot 4$ & 0.0 & NS \\
\hline $18: 4 n-3$ & 0.6 & 0.0 & 0.6 & 0.0 & 0.6 & 0.0 & 0.6 & 0.0 & NS \\
\hline $20: 3 n-3$ & $0 \cdot 1^{a}$ & 0.0 & $0 \cdot 1^{b}$ & 0.0 & $0 \cdot 1^{\mathrm{b}}$ & 0.0 & $0.1^{b}$ & 0.0 & $\star *$ \\
\hline $20: 4 n-3$ & 0.2 & 0.0 & 0.2 & 0.0 & 0.2 & 0.0 & 0.2 & 0.0 & NS \\
\hline $20: 5 n-3$ & $2 \cdot 4^{a}$ & 0.0 & $2 \cdot 1^{b}$ & 0.1 & $2 \cdot 1^{\mathrm{b}}$ & 0.1 & $2 \cdot 0^{\mathrm{b}}$ & 0.1 & * \\
\hline $22: 5 n-3$ & 0.5 & 0.0 & 0.4 & 0.0 & 0.4 & 0.0 & 0.4 & 0.0 & NS \\
\hline $22: 6 n-3$ & $2 \cdot 8^{\mathrm{a}}$ & 0.1 & $2 \cdot 3^{b}$ & 0.1 & $2 \cdot 2^{b}$ & 0.1 & $2 \cdot 3^{b}$ & 0.1 & * \\
\hline$\Sigma$ SFA & $17 \cdot 7$ & 0.2 & $17 \cdot 6$ & 0.4 & $17 \cdot 1$ & 0.1 & $17 \cdot 2$ & 0.2 & NS \\
\hline$\Sigma$ MUFA & 51.9 & 0.2 & $52 \cdot 7$ & 0.3 & $52 \cdot 7$ & 0.2 & $52 \cdot 8$ & 0.2 & NS \\
\hline$\Sigma$ PUFA & $30 \cdot 3$ & 0.2 & $29 \cdot 7$ & 0.3 & $30 \cdot 2$ & 0.2 & $30 \cdot 0$ & 0.2 & NS \\
\hline \multicolumn{10}{|l|}{ Polar lipids } \\
\hline $16: 0$ & $15 \cdot 4$ & 0.1 & $15 \cdot 5$ & 0.2 & $15 \cdot 3$ & 0.1 & $15 \cdot 6$ & 0.1 & NS \\
\hline $18: 0$ & $7 \cdot 2$ & 0.1 & $7 \cdot 4$ & 0.1 & $7 \cdot 2$ & 0.1 & $7 \cdot 2$ & 0.0 & NS \\
\hline $18: 1$ & 0.1 & 0.0 & 0.1 & 0.0 & 0.1 & 0.0 & 0.1 & 0.0 & NS \\
\hline $18: 2 n-6$ & $13 \cdot 1$ & 0.2 & $13 \cdot 3$ & 0.2 & $13 \cdot 4$ & 0.3 & 13.5 & 0.2 & NS \\
\hline $18: 3 n-6$ & 0.4 & 0.0 & 0.4 & 0.0 & 0.4 & 0.0 & 0.4 & 0.0 & NS \\
\hline $20: 2 n-6$ & 0.9 & 0.0 & 1.0 & 0.0 & 1.0 & 0.0 & 1.0 & $0 \cdot 1$ & NS \\
\hline $20: 3 n-6$ & 0.3 & 0.0 & 0.3 & 0.0 & 0.3 & 0.0 & 0.2 & 0.0 & NS \\
\hline $20: 4 n-6$ & 1.5 & 0.0 & 1.5 & 0.0 & 1.5 & 0.0 & 1.5 & 0.0 & NS \\
\hline $18: 3 n-3$ & 3.4 & 0.1 & 3.5 & 0.1 & $3 \cdot 4$ & 0.1 & 3.5 & 0.1 & NS \\
\hline $18: 4 n-3$ & 0.3 & 0.0 & 0.3 & 0.0 & 0.3 & 0.0 & 0.3 & 0.0 & NS \\
\hline $20: 3 n-3$ & 0.1 & 0.0 & 0.1 & 0.0 & 0.2 & 0.0 & $0 \cdot 1$ & 0.0 & NS \\
\hline $20: 4 n-3$ & $0.2^{a}$ & 0.0 & $0.2^{\mathrm{a}}$ & 0.0 & $0.3^{b}$ & 0.0 & $0.2^{\mathrm{a}}$ & 0.0 & * \\
\hline $20: 5 n-3$ & $6 \cdot 6$ & 0.1 & 6.5 & 0.2 & $6 \cdot 4$ & 0.1 & 6.5 & 0.1 & NS \\
\hline $22: 5 n-3$ & $1 \cdot 1$ & 0.0 & $1 \cdot 1$ & 0.0 & $1 \cdot 1$ & 0.0 & $1 \cdot 1$ & 0.0 & NS \\
\hline $22: 6 n-3$ & $17 \cdot 7$ & 0.2 & 17.5 & 0.4 & $16 \cdot 8$ & 0.6 & $17 \cdot 2$ & 0.2 & NS \\
\hline$\Sigma$ SFA & $24 \cdot 6$ & 0.2 & $24 \cdot 8$ & 0.3 & $24 \cdot 7$ & 0.2 & $24 \cdot 7$ & 0.3 & NS \\
\hline$\Sigma$ MUFA & 29.8 & 0.1 & 29.7 & 0.3 & $30 \cdot 3$ & 0.3 & $29 \cdot 7$ & 0.1 & NS \\
\hline$\Sigma$ PUFA & $45 \cdot 6$ & 0.1 & $45 \cdot 5$ & 0.4 & $45 \cdot 0$ & 0.4 & $45 \cdot 6$ & 0.2 & NS \\
\hline
\end{tabular}

XH, extra-high-HUFA diet; HH, high-HUFA diet; LH, low-HUFA diet; XLH, extra-low-HUFA diet.

a,b Mean values within a row with unlike superscript letters were significantly different $(P<0.05)$

${ }^{\star} P<0.05,{ }^{* \star} P<0.01$.

clonal selection, metabolic differentiation, hepatocyte polyploidisation and epigenetic modifications. In the present study, the memory of metabolic process in juveniles could be due to epigenetic modifications of the $\Delta 6 \mathrm{D}$ and PPAR genes. Epigenetic modifications are modifications of DNA and covalent modifications of histones, which condition the accessibility of chromatin to transcription factors, facilitating the recognition of genes to be expressed or silenced, transiently or permanently, by these factors ${ }^{(18)}$. The hepatocyte nuclear factor $1 \alpha(\mathrm{HNF} 1 \alpha)$ has been identified as an homeoprotein expressed in liver, kidney, pancreas and digestive tract that could activate transcription through participation in the recruitment of the general transcription machinery to the promoter, or through the remodelling of chromatin structure and demethylation that would allow transcription factors to interact with their cognate cis-acting elements ${ }^{(19)}$.

The relatively high level of $n$ - 3 HUFA measured in the PL $v$. NL of larvae and juveniles was in agreement with the preferential incorporation of these fatty acids in PL contributing to the maintenance of PL quality ${ }^{(20)}$. Although AA, EPA and DHA were selectively incorporated in the PL of larvae, low values were observed in the PL of fish fed low- $n-3$ HUFA diets ( $\mathrm{LH} 1$ and $\mathrm{XLH} 1$ ), revealing an $n-3$ deficiency in these groups. Even though growth was similar in LH1 and XLH1 larvae, the HUFA content in PL was different within these groups, in accordance with values previously observed in day 45 sea bass larvae fed a diet with similar EPA + DHA content ${ }^{(7)}$. The $\mathrm{XH} 1$ groups showed an 


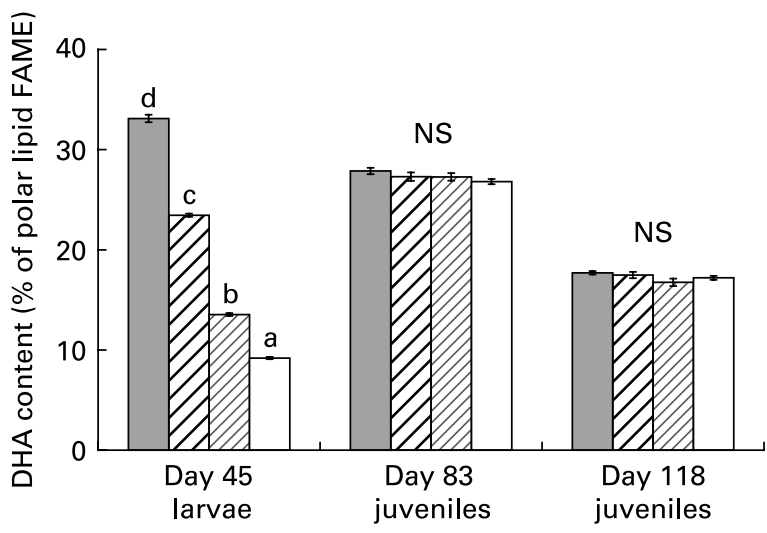

Fig. 7. DHA content in polar lipids (\% fatty acid methyl esters; FAME) of day 45 larvae $(n 4)$, and day $83(n 4)$ and day 118 juveniles fed the restricted diet ( $n$ 4), according to the larval initial diet. ( $\square$ ), Extra-high-highly unsaturated

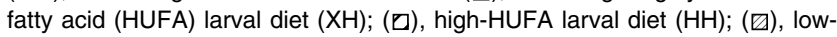
HUFA larval diet (LH); ( $\square$ ), extra-low-HUFA larval diet (XL). The effect of the initial diet was statistically significant at day $45(P<0.001)$. ${ }^{\mathrm{a}, \mathrm{b}, \mathrm{c}, \mathrm{d}}$ Mean values at a time point with unlike letters were significantly different $(P<0.05)$.

exceptionally high DHA content in both PL and NL in day 45 larvae, which has rarely been observed in aquaculture, except in larvae fed on natural plankton or on rotifers enriched with $\mathrm{DHA}^{(21,22)}$. The AA deficiency observed in larvae fed the LH1 and XLH1 diets, while its precursor $18: 2 n-6$ increased in these groups, can be explained by the low activity of $\Delta-5$ desaturase in these groups. This hypothesis was in accordance with the very low enzymic activity of $\Delta$-5-desaturase compared with that of $\Delta 6 \mathrm{D}$ measured in seabream (Sparus aurata $)^{(23)}$. That $18: 4 n-3$ was not increased could be due to the higher concentration of this fatty acid in larvae combined with the low concentration of its precursor $(18: 3 n-3)$ in the diets used, as shown in microsomes of dogs and rats ${ }^{(24)}$. Moreover, as the level of $18: 2 n-6$ is 10 -fold higher than $18: 3 n-3$ in the diets, its bioconversion could be stimulated in larvae even although $\Delta 6 \mathrm{D}$ usually shows higher affinity with $n-3$ fatty acids than with $n-6$ fatty acids ${ }^{(25)}$. This suggested that production of $18: 4 n-3$ could exist in $n-3$ HUFA-deprived larvae, even if it is not observable with the techniques used. Thus, the high level of $n-6$ fatty acids in the diet may mask effects on the $n-3$ HUFA synthesis pathway.

Day 83 R-juveniles showed a similar composition in NL, while at day 118, several n-3 HUFA, including EPA and DHA, were present at a higher level in the NL of XH $2_{R}$ juveniles than in others. This indicated that differences observed at day 118 could be the consequence of the growth-dependent dilution effect of initial (day 83) fatty acid stores in the smaller fish ${ }^{(26)}$. The DHA content in the PL of R-juveniles at day 118 (about $17 \% ; P<0.001)$ was intermediate between the DHA content of $n$-3-deprived LH1 and -sufficient $\mathrm{HH} 1$ larvae, and significantly lower than in C-groups (about $24 \%$ ) and day 83 juveniles (about $27 \%$ ). This was in agreement with a previous study ${ }^{(9)}$, which showed that sea bass juveniles fed at or above requirement had a minimal DHA content in PL of about $20 \%$ of total fatty acids. The fatty acid content in the PL of day 118 juveniles remained similar in all groups, except for $20: 4 n-3$, which was at a higher level in $\mathrm{XH} 2_{\mathrm{R}}$ groups than in others. In a previous experiment $^{(8)}$, a slightly higher DHA content in PL was found in juveniles conditioned with an $n-3$ HUFA-deprived diet during the larval stage than in others, suggesting an enhanced capacity to adapt to a HUFA-restricted diet. A similar result was not obtained in the present study, which could be the consequence of technical differences between the two experiments, or to biological mechanisms. Irrespective, the two studies showed that the observed stimulation of $\Delta 6 \mathrm{D}$ mRNA was not linked to an increase in PL $n-3$ HUFA content, and this could be due to the very low rate of desaturation already described for European sea bass, even when up-regulated by $\operatorname{diet}^{(27)}$.

\section{Conclusion}

The present study demonstrated an amplified stimulation of $\Delta 6 \mathrm{D}$ mRNA induced by dietary $n-3$ HUFA deficiency in juveniles pre-conditioned with a low dietary $n-3$ HUFA content during the larval stage, and persisting in young juveniles. However, this did not have a noticeable influence on fatty acid composition and growth performances in juveniles challenged with a HUFA-restricted diet. The present results also suggested the involvement of PPAR in the regulation of $\triangle 6 \mathrm{D}$ gene expression. Further studies concerning enzymic activities of $\triangle 6 \mathrm{D}$ and PPAR gene regulation are required to further investigate and understand the metabolic pathways for HUFA synthesis in marine fish.

\section{Acknowledgements}

The present study was supported by Ifremer (Institut Français pour la recherche et l'exploitation de la mer) and INRA (Institut National de Recherche Agronomique) grants to the first author (M. V.). M. V. conducted the analysis of growth and molecular biology, as well as the statistical analysis of all data. J. H. R. was responsible for the lipid analysis, J. L. Z. I. contributed to the analysis of molecular biology, and D. R. T. contributed to the lipid analysis and the English corrections. J. P.-L. R. contributed to all data analysis, as she was the PhD supervisor of the first author (M. V.). None of the authors has any conflicts of interest. We are grateful to N. Le Bayon, H. Le Delliou, M. M. Le Gall, P. Quazuguel and A. Sévère for their technical assistance.

\section{References}

1. Ringo E, Lodemel JB, Myklebust R, et al. (2002) The effects of soybean, linseed and marine oils on aerobic gut microbiota of arctic charr Salvelinus alpinus L. before and after challenge with Aeromonas salmonicida. Aquac Res 33, 591-606.

2. Mourente $\mathrm{G} \&$ Tocher DR (1994) In vivo metabolism of $\left[1-{ }^{14} \mathrm{C}\right]$ linolenic acid $(18: 3 n-3)$ and $\left[1-{ }^{14} \mathrm{C}\right]$ eicosapentaenoic acid $(20: 5 n-3)$ in marine fish: time-course of the desaturation/ elongation pathway. Biochim Biophys Acta 1212, 109-118.

3. Sargent JR, Tocher DR \& Bell JG (2002) The lipids. In Fish Nutrition, 3rd ed., pp. 182-259 [JE Halver and RW Hardy, editors]. London: Academic Press.

4. Cho HP, Nakamura M \& Clarke SD (1999) Cloning, expression, and nutritional regulation of the mammalian $\Delta-6$ desaturase. J Biol Chem 274, 37335-37339.

5. Owen JM, Adron JW, Middleton C, et al. (1975) Elongation and desaturation of dietary fatty acids in turbot (Scophtalamus maximus L.), and rainbow trout (Salmo gairdnerii Rich.). Lipids 10 , $528-531$ 
6. Lucas A (1998) Programming by early nutrition: an experimental approach. J Nutr 128, Suppl. 1, 401S-406S.

7. Vagner M, Robin JH, Zambonino Infante JL, et al. (2007) Combined effect of dietary HUFA level and temperature on sea bass (D. labrax) larvae development. Aquaculture 266, 179-190.

8. Vagner M, Zambonino Infante JL, Robin JH, et al. (2007) Is it possible to influence European sea bass (Dicentrarchus labrax) juvenile metabolism by a nutritional conditioning during larval stage? Aquaculture 267, 165-174.

9. Skalli A \& Robin JH (2004) Requirement of $n$-3 long chain polyunsaturated fatty acids for European sea bass (Dicentrachus labrax) juveniles: growth and fatty acid composition. Aquaculture 240, 399-415.

10. Olsvik P, Lie K, Jordal A, et al. (2005) Evaluation of potential reference genes in real time RT-PCR studies of Atlantic salmon. BMC Mol Biol 17, 6-21.

11. Gause WC \& Adamovicz J (1994) The use of the PCR to quantitate gene expression. PCR Methods Appl 3, 123-135.

12. Association of Official Analytical Chemists (1984) Official Methods of Analysis of the Association of Analytical Chemists, pp. 1141 [Williams S, editor]. Arlington, VA: AOAC.

13. Zambonino Infante JL \& Cahu CL (1999) High dietary lipid levels enhance digestive tract maturation and improve Dicentrarchus labrax larval development. J Nutr 129, 1195-1200.

14. Le Milinaire C (1984) Etude du besoin en acides gras essentiels pour la larve de turbot (Psetta maxima L.) pendant la phase d'alimentation avec le rotifère Brachionus plicatilis (Study of essential fatty-acid requirements for the turbot larva (Psetta maxima L.) during the feeding phase with the rotifer Brachionus plicatilis), p. 168. PhD thesis: Université de Brest.

15. Seiliez I, Panserat S, Corraze G, et al. (2003) Cloning and nutritional regulation of a $\Delta 6$-desaturase-like enzyme in the marine teleost gilthead seabream (Sparus aurata). Comp Biochem Physiol B Biochem Mol Biol 135, 449-460.

16. Buzzi M, Henderson RJ \& Sargent JR (1997) Biosynthesis of docosahexaenoic acid in trout hepatocytes proceeds via 24-carbon intermediates. Comp Biochem Physiol B Biochem Mol Biol 116, 263-267.
17. Nakamura MT \& Nara TY (2003) Essential fatty acid synthesis and its regulation in mammals. Prostaglandins Leukot Essent Fatty Acids 68, 145-150.

18. Waterland RA \& Garza C (1999) Potential mechanisms of metabolic imprinting that lead to chronic diseases. Am J Clin Nutr 69, 179-197.

19. Pontoglio M, Faust DM, Doyen A, et al. (1997) Hepatocyte nuclear factor 1- $\alpha$ gene inactivation impairs chromatin remodelling and demethylation of the phenylalanine hydroxylase gene. Mol Cell Biol 17, 4948-4956.

20. Linares F \& Henderson RJ (1991) Incorporation of ${ }^{14} \mathrm{C}$-labelled polyunsaturated fatty acids by juvenile turbot Scophtalmus maximus (L.) in vivo. J Fish Biol 38, 335-347.

21. Van Der Meeren T, Klugsoyr J, Wilhelmsen S, et al. (1993) Fatty acid composition of unfed cod larvae Gadus morhua L. and cod larvae feeding on natural plankton in large enclosures. $J$ World Aquacult Soc 24, 167-185.

22. Garcia AS, Parrish CC \& Brown JA (2008) A comparison among differently enriched rotifers (Brachionus plicatilis) and their effect on Atlantic cod (Gadus morhua) larvae early growth, survival and lipid composition. Aquac Nutr 14, 14-30.

23. Tocher DR \& Ghioni C (1999) Fatty acid metabolism in marine fish: low activity of fatty acyl $\Delta-5$ desaturation in gilthead seabream (Sparus aurata) cells. Lipids 34, 433-440.

24. Dunbar BL \& Bauer JE (2002) Conversion of essential fatty acids by $\Delta$ 6-desaturase in dog liver microsomes. $J$ Nutr 132, $1701-1703$.

25. Zheng X, Seiliez I, Hastings N, et al. (2004) Charactarization and comparison of fatty acyl $\Delta 6$-desaturase cDNAs from freshwater and marine teleost fish species. Comp Biochem Physiol B Biochem Mol Biol 139, 269-279.

26. Robin JH, Regost C, Arzel J, et al. (2003) Fatty acid profile of fish following a change in dietary fatty acid source: model of fatty acid composition with a dilution hypothesis. Aquaculture 225, 283-293.

27. Mourente G, Dick JR, Bell JG, et al. (2005) Effect of partial substitution of dietary fish oil by vegetable oils on desaturation and oxidation of $\left[1-{ }^{14} \mathrm{C}\right] 18: 3 n-3$ and $\left[1-{ }^{14} \mathrm{C}\right] 20: 5 n-3$ in hepatocytes and enterocytes of European sea bass (Dicentrarchus labrax L.). Aquaculture 248, 173-186. 